\title{
Synthesis of chiral 3-substituted 3-amino-2-oxindoles through enantioselective catalytic nucleophilic additions to isatin imines
}

\author{
Hélène Pellissier
}

\author{
Review \\ Address: \\ Aix-Marseille Univ, CNRS, Centrale Marseille, iSm2, Marseille, France \\ Email: \\ Hélène Pellissier - h.pellissier@univ-amu.fr \\ Keywords: \\ asymmetric synthesis; chiral 3-amino-2-oxindoles; chirality; isatin \\ imines; nucleophilic addition \\ Beilstein J. Org. Chem. 2018, 14, 1349-1369. \\ doi:10.3762/bjoc. 14.114 \\ Received: 27 February 2018 \\ Accepted: 17 May 2018 \\ Published: 06 June 2018 \\ Associate Editor: S. Bräse \\ (C) 2018 Pellissier; licensee Beilstein-Institut. \\ License and terms: see end of document.
}

\begin{abstract}
This review collects the recent developments in the synthesis of chiral 3-substituted 3-amino-2-oxindoles based on enantioselective catalytic nucleophilic additions to isatin imines published since the beginning of 2015 .
\end{abstract}

\section{Introduction}

Chiral oxindoles represent an important class of products widely present in nature and exhibiting many biological activities. Among them, chiral 3-substituted 3-amino-2-oxindoles constitute privileged candidates in medicinal chemistry [1-8]. Consequently, the development of novel catalytic routes to produce these compounds is highly desired [9-19] with a special mention for organocatalyzed methodologies $[10,13]$. The simplest method to prepare chiral quaternary 3-amino-2-oxindoles is based on enantioselective catalytic nucleophilic additions to isatin imines. This is not only because of the easy access to isatin imines, but also by the possibility of using a wide range of nucleophiles, thus increasing the structural diversity of the resulting products. The first asymmetric catalytic versions were reported only in the 2010 s despite tremendous achievements in catalytic asymmetric imine addition reactions [20-22]. Ever since, a number of catalytic asymmetric nucleo- philic additions to isatin imines have been developed, including Mannich reactions, aza-Morita-Baylis-Hillman reactions, Friedel-Crafts reactions, aza-Henry reactions, additions of heteronucleophiles, Strecker reactions, among others. The goal of this review is to update the catalytic asymmetric synthesis of chiral 3-substituted 3-amino-2-oxindoles based on enantioselective nucleophilic additions to isatin imines reported since 2015, since this field was recently reviewed by Chimni et al. [16]. It is divided into six parts, dealing successively with enantioselective Mannich reactions, aza-Morita-Baylis-Hillman reactions, Friedel-Crafts reactions, aza-Henry reactions, domino reactions initiated by nucleophilic additions to isatin imines, and miscellaneous reactions. Most of the reactions depicted in this review have been promoted by a wide variety of chiral organocatalysts but chiral metal catalysts have also proved to be highly efficient for a range of transformations. 


\section{Review}

\section{Enantioselective Mannich reactions Organocatalyzed reactions}

Originally, the Mannich reaction is a three-component process occurring between an aldehyde, an amine and a ketone, providing $\beta$-amino carbonyl compounds [23-25].

An extensively used two-component variant of this reaction consists in using a preformed imine. Among chiral metal complexes, a wide variety of organocatalysts [26-34] has been used to promote asymmetric Mannich reactions. Among them, cinchona alkaloid 1 was employed in 2015 by Enders et al. at a remarkably low catalyst loading $(0.0225 \mathrm{~mol} \%)$ to promote the enantioselective Mannich reaction of ethyl nitroacetate (2) with $\mathrm{N}$-Boc-isatin imines 3 [35]. The process afforded, after a subsequent denitration, the corresponding chiral 3-amino-2-oxindoles 4 in moderate to high yields (51-91\%) and uniformly high enantioselectivities $(92-99 \%$ ee), as shown in Scheme 1. Common protecting groups $\left(\mathrm{R}^{1}\right)$, such as methyl, ethyl, 4-methoxybenzyl, methoxymethyl, phenyl and benzyl, were tolerated as well as various substituents $\left(\mathrm{R}^{2}\right)$ on the aromatic ring of the isatins, including electron-donating and electron- withdrawing groups. The lowest yield (51\%) was obtained in the reaction of a fluorinated isatin imine $\left(R^{1}=M e, R^{2}=7-F\right)$. The utility of this methodology was demonstrated by its application in the formal synthesis of the anticancer agent AG-041R. Furthermore, several of the formed products were converted into useful intermediates for the synthesis of pyrroloindoline alkaloids and related drugs, such as psychotrimine and (+)-folicanthine.

Later in 2016, Trivedi et al. reported the synthesis of chiral 3-amino-2-oxindoles through the Mannich reaction of $N$-Bocisatin imines 3 with 1,3-dicarbonyl compounds 5 performed in the presence of chiral cinchona alkaloid-derived squaramide 6 [36]. A range of chiral 3-amino-2-oxindoles 7 was obtained under mild reaction conditions in high to quantitative yields (78-99\%) and uniformly excellent enantioselectivities (90-99\% ee) as shown in Scheme 2. In particular, various $\mathrm{N}$-Boc-ketimines exhibiting either electron-donating or electron-withdrawing groups at the 5 and 7 positions of the aryl moiety, including halogens such as fluoro, chloro, bromo and iodo groups, reacted smoothly with pentane-2,4-dione $\left(\mathrm{R}^{2}=\mathrm{R}^{3}=\mathrm{Me}\right)$ affording the products with both very high

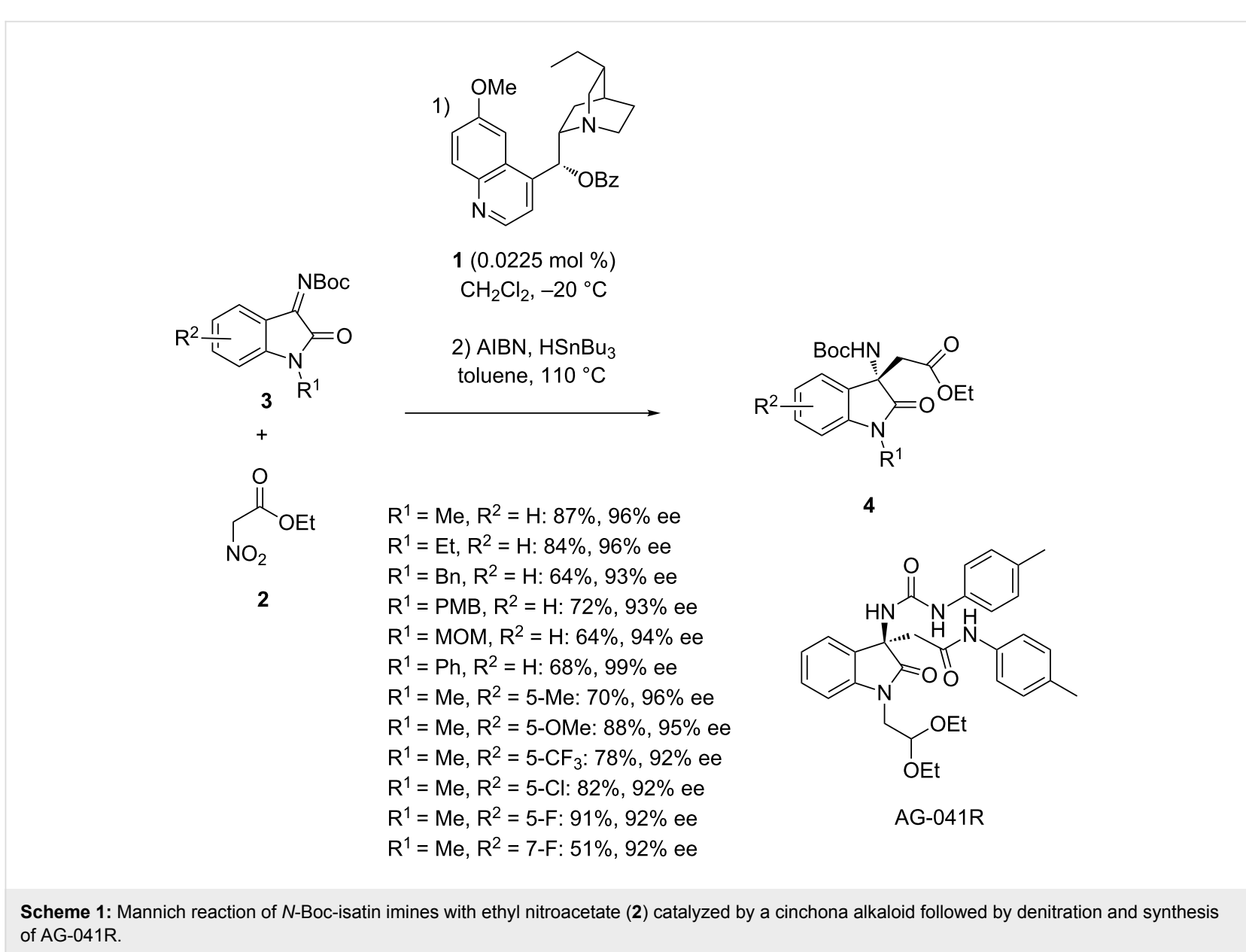



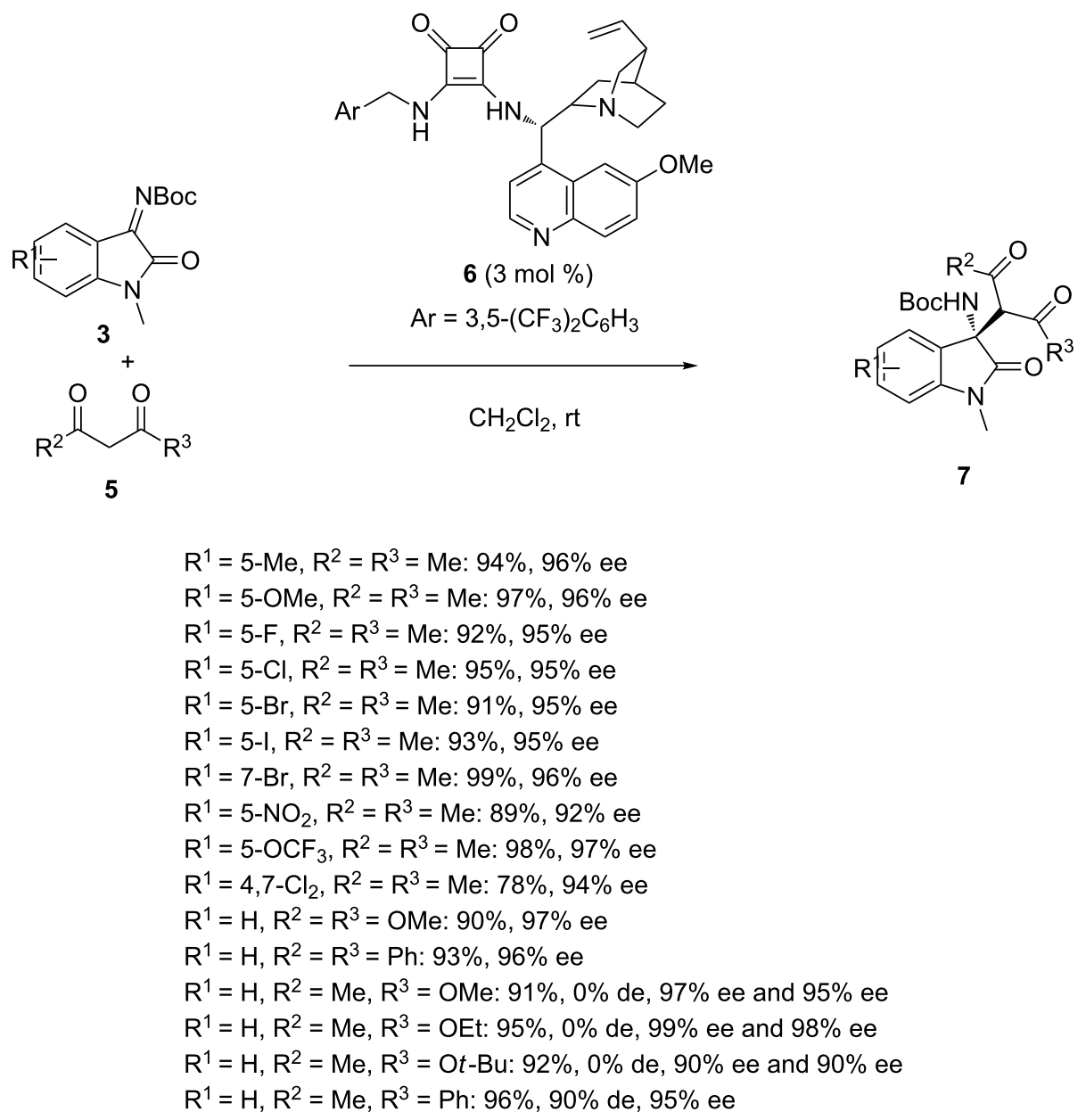

Scheme 2: Mannich reaction of $\mathrm{N}$-Boc-isatin imines with 1,3-dicarbonyl compounds catalyzed by a cinchona alkaloid-derived squaramide.

yields (89-99\%) and enantioselectivities (92-99\% ee). A lower yield (78\%) albeit combined with a high enantioselectivity (94\% ee) was obtained in the reaction of a dihalogenated isatin imine $\left(\mathrm{R}^{1}=4,7-\mathrm{Cl}_{2}\right)$. The scope of the process was also extended to 1,3-dicarbonyl compounds other than symmetrical pentane-2,4-dione, such as 1,3-diphenylpropane-1,3-dione $\left(\mathrm{R}^{2}=\mathrm{R}^{3}=\mathrm{Ph}\right)$, that also led by reaction with the unsubstituted isatin imine $\left(\mathrm{R}^{1}=\mathrm{H}\right)$ to the corresponding product in high yield (93\%) and enantioselectivity (96\% ee). Furthermore, unsymmetrical 1,3-dicarbonyl compounds, such as methyl acetoacetate $\left(\mathrm{R}^{2}=\mathrm{Me}, \mathrm{R}^{3}=\mathrm{OMe}\right)$, ethyl acetoacetate $\left(\mathrm{R}^{2}=\mathrm{Me}\right.$, $\left.\mathrm{R}^{3}=\mathrm{OEt}\right)$ and tert-butyl acetoacetate $\left(\mathrm{R}^{2}=\mathrm{Me}, \mathrm{R}^{3}=\mathrm{O} t\right.$ - $\left.\mathrm{Bu}\right)$ gave the corresponding Mannich products in high yields (91-95\%) and enantioselectivities (90-99\% ee), however as a 1:1 mixture of two diastereomers. In contrast, an excellent diastereoselectivity of $90 \%$ de was achieved in the reaction of 1-benzoylacetone $\left(\mathrm{R}^{2}=\mathrm{Me}, \mathrm{R}^{3}=\mathrm{Ph}\right)$ which afforded the corresponding single diastereoisomeric product in $96 \%$ yield and $95 \%$ ee.
In 2018, Tanyeli et al. reinvestigated this type of reactions in the presence of related cinchona alkaloid-derived squaramide catalyst 8 [37]. Indeed, the reaction of acetylacetone (5a) with various $\mathrm{N}$-alkoxycarbonylisatin imines $\mathbf{3}$ and $\mathbf{9}$ in the presence of only $1 \mathrm{~mol} \%$ of catalyst $\mathbf{8}$ in diethyl ether as solvent afforded at room temperature the corresponding chiral Mannich products $\mathbf{7}$ and $\mathbf{1 0}$ in low to nearly quantitative yields (29-98\%) combined with moderate to excellent enantioselectivities (41 to $>99 \%$ ee) as shown in Scheme 3. The lowest yields (29-42\%) were obtained for the ketimines having acetyl and ethyl substituents $\left(\mathrm{R}^{1}=\mathrm{Ac}\right.$ or $\left.\mathrm{Et}\right)$ at the amide nitrogen while better yields (70-98\%) were generally achieved for other (un)substituted isatin imines $\left(\mathrm{R}^{1}=\mathrm{Me}, \mathrm{Bn}, \mathrm{H}\right)$. Moreover, a range of electronwithdrawing and electron-donating groups on the aryl moiety $\left(\mathrm{R}^{2}\right)$ as well as different $N$-carbamoyl protecting groups $\left(\mathrm{R}^{3}=t-\mathrm{Bu}, \mathrm{Et}, \mathrm{Bn}\right)$ were compatible, providing generally high enantioselectivities ( 85 to $>99 \%$ ee), except for the 5-bromosubstituted derivative $\left(\mathrm{R}^{2}=5-\mathrm{Br}\right)$ which afforded the corresponding product in only $41 \%$ ee. An advantage of this 
<smiles></smiles>

$3,9^{R^{1}}$

$+$<smiles>CC(=O)CC(C)=O</smiles>

$5 a$<smiles>[R1]Nc1c(NC(c2ccnc3ccc(OC)cc23)C2CN3CCC(C=C)C2C3)c(=O)c1=O</smiles>

$8(1 \mathrm{~mol} \%)$

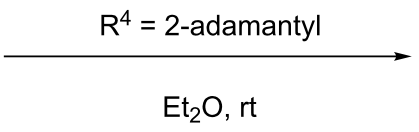

$\mathrm{Et}_{2} \mathrm{O}, \mathrm{rt}$

7,10

$$
\begin{aligned}
& \mathrm{R}^{1}=\mathrm{Me}, \mathrm{R}^{2}=\mathrm{H}, \mathrm{R}^{3}=t-\mathrm{Bu}: 92 \%, 99 \% \text { ee } \\
& \mathrm{R}^{1}=\mathrm{R}^{2}=\mathrm{H}, \mathrm{R}^{3}=t-\mathrm{Bu}: 97 \%, 98 \% \text { ee } \\
& \mathrm{R}^{1}=\mathrm{Ac}, \mathrm{R}^{2}=\mathrm{H}, \mathrm{R}^{3}=t-\mathrm{Bu}: 29 \%, 92 \% \text { ee } \\
& \mathrm{R}^{1}=\mathrm{Bn}, \mathrm{R}^{2}=\mathrm{H}, \mathrm{R}^{3}=t \text {-Bu: } 96 \%, 99 \% \text { ee } \\
& \mathrm{R}^{1}=\mathrm{Et}, \mathrm{R}^{2}=\mathrm{H}, \mathrm{R}^{3}=t-\mathrm{Bu}: 42 \%, 99 \% \text { ee } \\
& \mathrm{R}^{1}=\mathrm{R}^{2}=\mathrm{H}, \mathrm{R}^{3}=\mathrm{Et}: 70 \%, 96 \% \text { ee } \\
& \mathrm{R}^{1}=\mathrm{R}^{2}=\mathrm{H}, \mathrm{R}^{3}=\mathrm{Bn}: 72 \%, 91 \% \text { ee } \\
& \mathrm{R}^{1}=\mathrm{Me}, \mathrm{R}^{2}=\mathrm{H}, \mathrm{R}^{3}=\mathrm{Bn}: 88 \%, 97 \% \text { ee } \\
& \mathrm{R}^{1}=\mathrm{Me}, \mathrm{R}^{2}=\mathrm{H}, \mathrm{R}^{3}=\mathrm{Et}: 81 \%, 98 \% \text { ee } \\
& \mathrm{R}^{1}=\mathrm{Me}, \mathrm{R}^{2}=5-\mathrm{Me}, \mathrm{R}^{3}=t-\mathrm{Bu}: 92 \%,>99 \% \text { ee } \\
& \mathrm{R}^{1}=\mathrm{Me}, \mathrm{R}^{2}=5-\mathrm{Me}, \mathrm{R}^{3}=t-\mathrm{Bu}: 89 \%, 97 \% \text { ee } \\
& \mathrm{R}^{1}=\mathrm{Me}, \mathrm{R}^{2}=7-\mathrm{Cl}, \mathrm{R}^{3}=t-\mathrm{Bu}: 94 \%, 97 \% \text { ee } \\
& \mathrm{R}^{1}=\mathrm{Me}, \mathrm{R}^{2}=6-\mathrm{Cl}, \mathrm{R}^{3}=t-\mathrm{Bu}: 95 \%, 85 \% \text { ee } \\
& \mathrm{R}^{1}=\mathrm{Me}, \mathrm{R}^{2}=6-\mathrm{Br}, \mathrm{R}^{3}=t-\mathrm{Bu}: 92 \%, 90 \% \text { ee } \\
& \mathrm{R}^{1}=\mathrm{Me}, \mathrm{R}^{2}=7-\mathrm{F}, \mathrm{R}^{3}=t-\mathrm{Bu}: 96 \%, 96 \% \text { ee } \\
& \mathrm{R}^{1}=\mathrm{H}, \mathrm{R}^{2}=5-\mathrm{Br}, \mathrm{R}^{3}=t-\mathrm{Bu}: 88 \%, 41 \% \text { ee } \\
& \mathrm{R}^{1}=\mathrm{H}, \mathrm{R}^{2}=5-\mathrm{F}, \mathrm{R}^{3}=t-\mathrm{Bu}: 98 \%, 88 \% \text { ee } \\
& \mathrm{R}^{1}=\mathrm{H}, \mathrm{R}^{2}=5,7-(\mathrm{Me})_{2}, \mathrm{R}^{3}=t-\mathrm{Bu}: 84 \%, 88 \% \text { ee }
\end{aligned}
$$

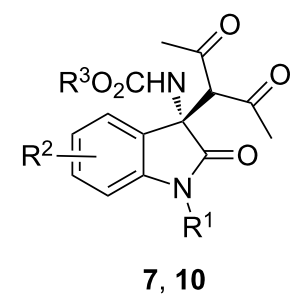

Scheme 3: Mannich reaction of $\mathrm{N}$-alkoxycarbonylisatin imines with acetylacetone catalyzed by a cinchona alkaloid-derived squaramide.

methodology was the use of a very low catalyst loading $(1 \mathrm{~mol} \%)$.

Earlier in 2016, Silvani and Lesma described the synthesis of chiral 3-amino-2-oxindole butenolides $\mathbf{1 1}$ on the basis of an enantioselective organocatalytic Mannich reaction between isatinderived benzhydrylketimines $\mathbf{1 2}$ and trimethylsiloxyfuran $\mathbf{1 3}$ [38]. Using $10 \mathrm{~mol} \%$ of another type of organocatalyst, such as chiral phosphoric acid 14 , the process led at $-40{ }^{\circ} \mathrm{C}$ in THF to the corresponding butenolides $\mathbf{1 1}$ in moderate to good yields (42-81\%), low to moderate diastereoselectivities (4-44\% de), and low to excellent enantioselectivities $(15-96 \%$ ee) for the major diastereomers formed (Scheme 4). In general, most of the isatin imines underwent the reaction smoothly with a good level of enantioselectivity ( $88-96 \%$ ee) and good yields $(78-81 \%)$ while the presence of a halogen substituent on the oxindole moiety $\left(\mathrm{R}^{2}=5-\mathrm{F}, 5-\mathrm{Cl}, 6-\mathrm{Br}\right)$ resulted in a lowering of both yields (42-68\%) and enantioselectivities (15-74\% ee).

In 2017, Shao et al. investigated the use of simple chiral primary amines to promote the enantioselective Mannich reaction of $N$-Boc-isatin imines 3 with aldehydes, such as acetaldehyde (15a) [39]. When these reactions were catalyzed by simple chiral primary amine 16 in aqueous THF at $0{ }^{\circ} \mathrm{C}$, they led to the corresponding chiral Mannich products 17 in good yields (74-81\%) and uniformly excellent enantioselectivities (90-94\% ee), as shown in Scheme 5. The synthetic utility of this novel methodology was demonstrated through the total synthesis of the natural product (-)-psychotriasine (Scheme 5) and the biologically active compound AG-041R (Scheme 1). 
<smiles>[R]C=C1C(=NC(c2ccccc2)c2ccco2)C(=O)N1[R1]</smiles>

13<smiles>O=P(O)(Oc1c(-c2ccccc2)cc2ccccc2c1-c1ccccc1)c1ccccc1</smiles>

$14(10 \mathrm{~mol} \%)$

THF, $-40^{\circ} \mathrm{C}$<smiles></smiles>

11

$\mathrm{R}^{1}=\mathrm{Bn}, \mathrm{R}^{2}=\mathrm{H}: 80 \%, 4 \%$ de, $90 \%$ and $92 \%$ ee

$\mathrm{R}^{1}=\mathrm{R}^{2}=\mathrm{H}: 78 \%, 26 \%$ de, $88 \%$ and $80 \%$ ee

$\mathrm{R}^{1}=\mathrm{Me}, \mathrm{R}^{2}=\mathrm{H}: 81 \%, 10 \%$ de, $91 \%$ and $68 \%$ ee

$R^{1}=P M B, R^{2}=H: 79 \%, 10 \%$ de, $89 \%$ and $84 \%$ ee

$\mathrm{R}^{1}=\mathrm{Tr}, \mathrm{R}^{2}=\mathrm{H}: 81 \%, 6 \%$ de, $96 \%$ and $4 \%$ ee

$\mathrm{R}^{1}=\mathrm{Bn}, \mathrm{R}^{2}=5-\mathrm{F}: 45 \%, 44 \%$ de, $15 \%$ and $1 \%$ ee

$\mathrm{R}^{1}=\mathrm{Bn}, \mathrm{R}^{2}=5-\mathrm{Cl}: 42 \%, 40 \%$ de, $74 \%$ and $26 \%$ ee

$R^{1}=B n, R^{2}=6-B r: 65 \%, 40 \%$ de, $42 \%$ and $31 \%$ ee

$R^{1}=M e, R^{2}=6-B r: 68 \%, 24 \%$ de, $32 \%$ and $31 \%$ ee

Scheme 4: Mannich reaction of isatin-derived benzhydrylketimines with trimethylsiloxyfuran catalyzed by a phosphoric acid<smiles>[R1][R11]1ccc2c(c1)N([R2])C(=O)C2=[N+]([O-])OC(C)=O</smiles>

$\overbrace{\mathrm{NH}_{2}}^{t-\mathrm{Bu}} \mathrm{NEt}_{2}$

$16(20 \mathrm{~mol} \%)$

$m-\mathrm{O}_{2} \mathrm{NC}_{6} \mathrm{H}_{4} \mathrm{CO}_{2} \mathrm{H}(20 \mathrm{~mol} \%)$

$\mathrm{H}_{2} \mathrm{O} / \mathrm{THF}, 0^{\circ} \mathrm{C}$<smiles>[R1]COC(=O)N[C@@]1(CCO)C(=O)N([R])c2cc[R1]([H])cc21</smiles>

17

$R^{1}=H, R^{2}=B n: 80 \%, 92 \%$ ee

$\mathrm{R}^{1}=\mathrm{H}, \mathrm{R}^{2}=\mathrm{Me}: 76 \%, 94 \%$ ee

$\mathrm{R}^{1}=\mathrm{H}, \mathrm{R}^{2}=$ allyl: $80 \%, 91 \%$ ee

$\mathrm{R}^{1}=\mathrm{H}, \mathrm{R}^{2}=\mathrm{CH}_{2} \mathrm{CH}(\mathrm{OEt})_{2}: 81 \%, 93 \%$ ee

$\mathrm{R}^{1}=\mathrm{R}^{2}=\mathrm{H}: 76 \%, 92 \%$ ee

$\mathrm{R}^{1}=5-\mathrm{Me}, \mathrm{R}^{2}=\mathrm{Bn}: 81 \%, 93 \%$ ee

$R^{1}=5-O M e, R^{2}=B n: 78 \%, 91 \%$ ee

$\mathrm{R}^{1}=5-\mathrm{Cl}, \mathrm{R}^{2}=\mathrm{Bn}: 80 \%, 90 \%$ ee

$\mathrm{R}^{1}=5-\mathrm{F}, \mathrm{R}^{2}=\mathrm{Bn}: 74 \%, 92 \%$ ee

$\mathrm{R}^{1}=6-\mathrm{Cl}, \mathrm{R}^{2}=\mathrm{Bn}: 75 \%, 90 \%$ ee

$\mathrm{R}^{1}=7-\mathrm{Cl}, \mathrm{R}^{2}=\mathrm{Bn}: 79 \%, 91 \%$ ee

$\mathrm{R}^{1}=7-\mathrm{CF}_{3}, \mathrm{R}^{2}=\mathrm{Bn}: 80 \%, 90 \%$ ee

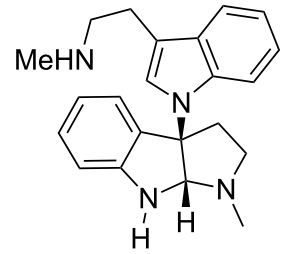

(-)-psychotriasine

Scheme 5: Mannich reaction of $\mathrm{N}$-Boc-isatin imines with acetaldehyde catalyzed by a primary amine.

By using another type of organocatalyst, such as L-diphenylprolinol trimethylsilyl ether $\mathbf{1 8}$, these authors showed that a range of $N$-Cbz-isatin imines 19 reacted with $\alpha$-substituted acetaldehydes $\mathbf{2 0}$ to give the corresponding chiral Mannich products $\mathbf{2 1}$ as major syn-diastereomers [39]. The latter were generally obtained with high syn/anti ratios (89:11 to 93:7) along with good yields $(62-83 \%)$ and uniformly excellent enantioselectivities (92-99\% ee), as shown in Scheme 6. 


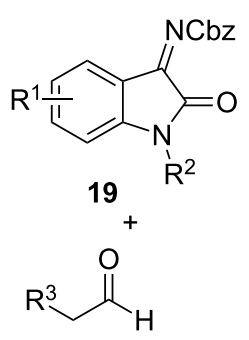

20

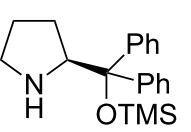

$18(20 \mathrm{~mol} \%)$

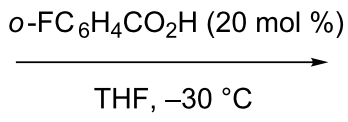

then $\mathrm{NaBH}_{4} / \mathrm{THF},-20^{\circ} \mathrm{C}$

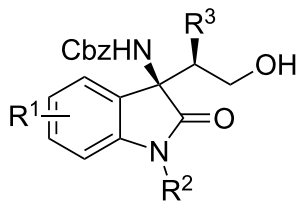

21

$$
\begin{aligned}
& \mathrm{R}^{1}=\mathrm{H}, \mathrm{R}^{2}=\mathrm{Bn}, \mathrm{R}^{3}=\mathrm{Et}: 81 \%, 84 \% \text { de, } 92 \% \text { ee } \\
& \mathrm{R}^{1}=\mathrm{H}, \mathrm{R}^{2}=\mathrm{Bn}, \mathrm{R}^{3}=\mathrm{Me}: 83 \%, 80 \% \text { de, } 98 \% \text { ee } \\
& \mathrm{R}^{1}=\mathrm{H}, \mathrm{R}^{2}=\mathrm{Bn}, \mathrm{R}^{3}=n-\mathrm{Bu}: 82 \%, 82 \% \text { de, } 94 \% \text { ee } \\
& \mathrm{R}^{1}=\mathrm{H}, \mathrm{R}^{2}=\mathrm{Bn}, \mathrm{R}^{3}=\text { allyl: } 80 \%, 78 \% \text { de, } 98 \% \text { ee } \\
& \mathrm{R}^{1}=\mathrm{H}, \mathrm{R}^{2}=\mathrm{Bn}, \mathrm{R}^{3}=\mathrm{iPr}: 62 \%, 82 \% \text { de, } 96 \% \text { ee } \\
& \mathrm{R}^{1}=\mathrm{H}, \mathrm{R}^{2}=\mathrm{Me}, \mathrm{R}^{3}=\mathrm{Et}: 80 \%, 78 \% \text { de, } 95 \% \text { ee } \\
& \mathrm{R}^{1}=5-\mathrm{Me}, \mathrm{R}^{2}=\mathrm{Bn}, \mathrm{R}^{3}=\mathrm{Et}: 78 \%, 78 \% \text { de, } 98 \% \text { ee } \\
& \mathrm{R}^{1}=5-\mathrm{OMe}, \mathrm{R}^{2}=\mathrm{Bn}, \mathrm{R}^{3}=\mathrm{Et}: 82 \%, 84 \% \text { de, } 96 \% \text { ee } \\
& \mathrm{R}^{1}=5,7-M e_{2}, \mathrm{R}^{2}=\mathrm{Bn}, \mathrm{R}^{3}=\mathrm{Et}: 79 \%, 78 \% \text { de, } 99 \% \text { ee } \\
& \mathrm{R}^{1}=5-\mathrm{F}, \mathrm{R}^{2}=\mathrm{Bn}, \mathrm{R}^{3}=\mathrm{Et}: 82 \%, 86 \% \text { de, } 99 \% \text { ee } \\
& \mathrm{R}^{1}=7-\mathrm{F}, \mathrm{R}^{2}=\mathrm{Bn}, \mathrm{R}^{3}=\mathrm{Et}: 81 \%, 84 \% \text { de, } 95 \% \text { ee } \\
& \mathrm{R}^{1}=6-\mathrm{Br}, \mathrm{R}^{2}=\mathrm{Bn}, \mathrm{R}^{3}=\mathrm{Et}: 80 \%, 80 \% \text { de, } 99 \% \text { ee }
\end{aligned}
$$

Scheme 6: Mannich reaction of $\mathrm{N}$-Cbz-isatin imines with aldehydes catalyzed by L-diphenylprolinol trimethylsilyl ether.

Along with enolates employed as nucleophilic partners in Mannich reactions, related reactions involving enamines have been developed. For example in 2018, Lu, Zhang and Shi reported the first catalytic asymmetric construction of the cyclic enaminone-based 3-substituted 3-amino-2-oxindole scaffold with potential bioactivity on the basis of enantioselective additions of cyclic enaminones to $N$-Boc-isatin imines [40]. As shown in Scheme 7, the addition of dimedone-derived enaminones 22 to a variety of $N$-Boc-isatin imines 3 was optimally promoted by chiral phosphoric acid 23 exhibiting a bulky 2,4,6(iPr) ${ }_{3} \mathrm{C}_{6} \mathrm{H}_{2}$ group, which provided at $50{ }^{\circ} \mathrm{C}$ in 1,4-dioxane as solvent the corresponding chiral cyclic enaminone-based 3-substituted 3-amino-2-oxindoles 24 in moderate to quantitative yields (54-99\%) and good to high enantioselectivities (84-96\% ee). The process was compatible with a wide range of $N$-Boc-isatin imines bearing various substituents, the electronic nature and position of which having no obvious effect on the enantioselectivity. Moreover, a variety of dimedone-derived enaminones bearing electronically different substituents at the ortho, meta and para-positions of the aniline moieties was compatible.

The scope of this methodology could be extended to another type of enaminones, such as hydroxyfuran-2-one-derived ones 25, which afforded by reaction with $N$-Boc-isatin imines 3 the corresponding chiral products $\mathbf{2 6}$ in moderate to excellent yields (58-99\%) and good to high enantioselectivities (81-97\% ee), as illustrated in Scheme 8 [40]. A preliminary evaluation on the cytotoxicity of some selected products revealed that two of them exhibited moderate to strong cytotoxicity to A549, 786-0, ECA109 and BT474 cancer cell lines.

\section{Metal-catalyzed reactions}

In addition to organocatalysts, chiral metal catalysts [41-47] have been recently applied to promote enantioselective Mannich reactions. As an example, in 2015 Feng et al. reported the enantioselective Mannich reaction of $N$-Boc-isatin imines 3 with silyl ketene imines 27 catalyzed using a combination of $\mathrm{Zn}(\mathrm{OTf})_{2}$ and chiral $N, N^{\prime}$-dioxide ligand 28 [48]. As shown in Scheme 9, this remarkable process afforded a wide range of chiral $\beta$-amino nitriles 29 exhibiting two vicinal tetrasubstituted stereocenters as almost single diastereomers ( $>90 \%$ de) in both uniformly excellent yields (90-98\%) and enantioselectivities (94-99\% ee). In only one case of substrate ( $\mathrm{Ar}=1-\mathrm{Naph})$, a lower yield (78\%) albeit combined with a comparable very good enantioselectivity ( $93 \%$ ee) was obtained.

The same year, $(S)$-BINOL-derived tin dibromide $\mathbf{3 0}$ was employed by Yanagisawa et al. to promote the enantioselective Mannich reaction of alkenyl trichloroacetate 31 with $N$-aryl- 


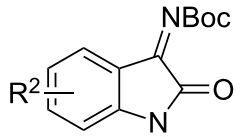

$3 \mathrm{R}^{1}$<smiles>[R]NC1=CC(=[OH+])CC(C)(C)C1</smiles>

22<smiles>O=P(O)(Oc1cc2ccccc2cc1Br)Oc1c(Br)cc2ccccc2c1-c1ccccc1</smiles>

$23(10 \mathrm{~mol} \%)$

$\mathrm{Ar}=2,4,6-(\mathrm{iPr})_{3} \mathrm{C}_{6} \mathrm{H}_{2}$

1,4-dioxane, $50{ }^{\circ} \mathrm{C}$

$3 \AA \mathrm{MS}$

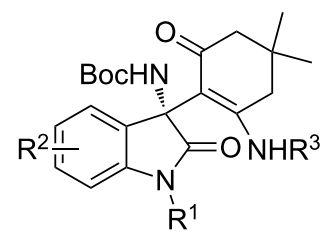

24

$\mathrm{R}^{1}=\mathrm{Bn}, \mathrm{R}^{2}=\mathrm{H}, \mathrm{R}^{3}=p-\mathrm{MeOC}_{6} \mathrm{H}_{4}: 73 \%, 96 \%$ ee

$\mathrm{R}^{1}=\mathrm{Bn}, \mathrm{R}^{2}=\mathrm{H}, \mathrm{R}^{3}=0-\mathrm{FC}_{6} \mathrm{H}_{4}: 80 \%, 91 \%$ ee

$\mathrm{R}^{1}=\mathrm{Bn}, \mathrm{R}^{2}=\mathrm{H}, \mathrm{R}^{3}=0-\mathrm{MeOC}_{6} \mathrm{H}_{4}: 54 \%, 84 \%$ ee

$\mathrm{R}^{1}=\mathrm{Bn}, \mathrm{R}^{2}=\mathrm{H}, \mathrm{R}^{3}=m-\mathrm{FC}_{6} \mathrm{H}_{4}: 92 \%, 94 \%$ ee

$\mathrm{R}^{1}=\mathrm{Bn}, \mathrm{R}^{2}=\mathrm{H}, \mathrm{R}^{3}=m$-Tol: $83 \%, 91 \%$ ee

$\mathrm{R}^{1}=\mathrm{Bn}, \mathrm{R}^{2}=\mathrm{H}, \mathrm{R}^{3}=m-\mathrm{MeOC}_{6} \mathrm{H}_{4}: 71 \%, 94 \%$ ee

$\mathrm{R}^{1}=\mathrm{Bn}, \mathrm{R}^{2}=\mathrm{H}, \mathrm{R}^{3}=p-\mathrm{FC}_{6} \mathrm{H}_{4}: 96 \%, 93 \%$ ee

$\mathrm{R}^{1}=\mathrm{Bn}, \mathrm{R}^{2}=\mathrm{H}, \mathrm{R}^{3}=p-\mathrm{ClC}_{6} \mathrm{H}_{4}: 98 \%, 94 \%$ ee

$\mathrm{R}^{1}=\mathrm{Bn}, \mathrm{R}^{2}=\mathrm{H}, \mathrm{R}^{3}=p$-Tol: $94 \%, 91 \%$ ee

$\mathrm{R}^{1}=\mathrm{Bn}, \mathrm{R}^{2}=\mathrm{H}, \mathrm{R}^{3}=\mathrm{Ph}: 99 \%, 90 \%$ ee

$R^{1}=B n, R^{2}=H, R^{3}=2-N a p h: 90 \%, 91 \%$ ee

$\mathrm{R}^{1}=\mathrm{Bn}, \mathrm{R}^{2}=4-\mathrm{Me}, \mathrm{R}^{3}=p-\mathrm{MeOC}_{6} \mathrm{H}_{4}: 78 \%, 95 \%$ ee

$\mathrm{R}^{1}=\mathrm{Bn}, \mathrm{R}^{2}=5-\mathrm{F}, \mathrm{R}^{3}=p-\mathrm{MeOC}_{6} \mathrm{H}_{4}: 81 \%, 92 \%$ ee

$\mathrm{R}^{1}=\mathrm{Bn}, \mathrm{R}^{2}=6-\mathrm{F}, \mathrm{R}^{3}=p-\mathrm{MeOC}_{6} \mathrm{H}_{4}: 80 \%, 93 \%$ ee

$\mathrm{R}^{1}=\mathrm{Bn}, \mathrm{R}^{2}=6-\mathrm{Cl}, \mathrm{R}^{3}=p-\mathrm{MeOC}_{6} \mathrm{H}_{4}: 62 \%, 96 \%$ ee

$\mathrm{R}^{1}=\mathrm{Bn}, \mathrm{R}^{2}=6-\mathrm{Br}, \mathrm{R}^{3}=p-\mathrm{MeOC}_{6} \mathrm{H}_{4}: 87 \%, 93 \%$ ee

$\mathrm{R}^{1}=\mathrm{Bn}, \mathrm{R}^{2}=7-\mathrm{F}, \mathrm{R}^{3}=p-\mathrm{MeOC}_{6} \mathrm{H}_{4}: 86 \%, 92 \%$ ee

$\mathrm{R}^{1}=\mathrm{Bn}, \mathrm{R}^{2}=7-\mathrm{Br}, \mathrm{R}^{3}=p-\mathrm{MeOC}_{6} \mathrm{H}_{4}: 99 \%, 92 \%$ ee

$\mathrm{R}^{1}=\mathrm{Bn}, \mathrm{R}^{2}=7-\mathrm{OMe}, \mathrm{R}^{3}=p-\mathrm{MeOC}_{6} \mathrm{H}_{4}: 81 \%, 92 \%$ ee

$\mathrm{R}^{1}=\mathrm{CH}_{2} p-\mathrm{Tol}, \mathrm{R}^{2}=\mathrm{H}, \mathrm{R}^{3}=p-\mathrm{MeOC}_{6} \mathrm{H}_{4}: 87 \%, 91 \%$ ee

Scheme 7: Addition of dimedone-derived enaminones to $\mathrm{N}$-Boc-isatin imines catalyzed by a phosphoric acid.<smiles>O=C([O-])N=C1C(=O)Nc2ccccc21</smiles>

$3 \mathrm{R}$<smiles>CCNC1=CC(=O)OC1</smiles>

25

\section{$23(20 \mathrm{~mol} \%)$}

1,4-dioxane, $50^{\circ} \mathrm{C}$

$3 \AA \mathrm{MS}$<smiles>[R1]N1C=C2COC(=O)C2(NC[AlH2])C1=O</smiles>

26

$\mathrm{R}=\mathrm{H}, \mathrm{Ar}=p-\mathrm{MeOC}_{6} \mathrm{H}_{4}: 86 \%, 81 \%$ ee

$\mathrm{R}=\mathrm{Me}, \mathrm{Ar}=\mathrm{Ph}: 99 \%, 90 \%$ ee

$\mathrm{R}=\mathrm{Ph}, \mathrm{Ar}=p-\mathrm{MeOC}_{6} \mathrm{H}_{4}: 99 \%, 91 \%$ ee

$\mathrm{R}=\mathrm{EtCO}, \mathrm{Ar}=\mathrm{Ph}: 63 \%, 86 \%$ ee

$\mathrm{R}=$ allyl, $\mathrm{Ar}=p-\mathrm{MeOC}_{6} \mathrm{H}_{4}: 99 \%, 82 \%$ ee

$\mathrm{R}=$ allyl, $\mathrm{Ar}=p-\mathrm{ClC}_{6} \mathrm{H}_{4}: 58 \%, 97 \%$ ee 
<smiles>CC(C)(C)ON=C1C(=O)N(Cc2ccccc2)c2cc[R]#cc21</smiles>

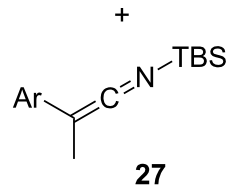

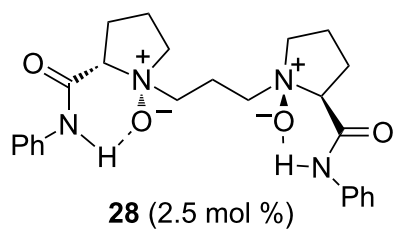

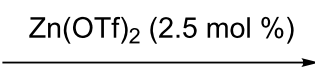

THF, $-45^{\circ} \mathrm{C}$

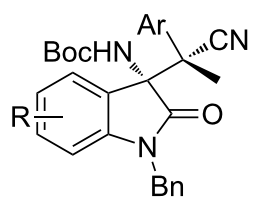

29

$>90 \%$ de

$\mathrm{Ar}=\mathrm{Ph}, \mathrm{R}=\mathrm{H}: 98 \%, 99 \%$ ee

$\mathrm{Ar}=\mathrm{Ph}, \mathrm{R}=5-\mathrm{F}: 93 \%, 99 \%$ ee

$\mathrm{Ar}=\mathrm{Ph}, \mathrm{R}=5-\mathrm{Cl}: 98 \%, 99 \%$ ee

$\mathrm{Ar}=\mathrm{Ph}, \mathrm{R}=5-\mathrm{Br}: 96 \%, 99 \%$ ee

$\mathrm{Ar}=\mathrm{Ph}, \mathrm{R}=5-\mathrm{I}: 98 \%, 98 \%$ ee

$\mathrm{Ar}=\mathrm{Ph}, \mathrm{R}=5-\mathrm{Me}: 98 \%, 99 \%$ ee

$\mathrm{Ar}=\mathrm{Ph}, \mathrm{R}=5-\mathrm{OMe}: 97 \%, 99 \%$ ee

$\mathrm{Ar}=\mathrm{Ph}, \mathrm{R}=5-\mathrm{OCF}_{3}: 93 \%, 97 \%$ ee

$\mathrm{Ar}=\mathrm{Ph}, \mathrm{R}=6-\mathrm{Cl}: 97 \%, 99 \% \mathrm{ee}$

$\mathrm{Ar}=\mathrm{Ph}, \mathrm{R}=6-\mathrm{Br}: 95 \%, 98 \%$ ee

$\mathrm{Ar}=\mathrm{Ph}, \mathrm{R}=7-\mathrm{F}: 98 \%, 99 \%$ ee

$\mathrm{Ar}=\mathrm{Ph}, \mathrm{R}=7-\mathrm{Cl}: 97 \%, 99 \% \mathrm{ee}$

$\mathrm{Ar}=\mathrm{Ph}, \mathrm{R}=7-\mathrm{Br}: 98 \%, 99 \%$ ee

$\mathrm{Ar}=\mathrm{Ph}, \mathrm{R}=7-\mathrm{CF}_{3}: 93 \%, 98 \%$ ee

$\mathrm{Ar}=\mathrm{Ph}, \mathrm{R}=5,7-\mathrm{Me}_{2}: 97 \%, 98 \%$ ee

$\mathrm{Ar}=0-\mathrm{Tol}, \mathrm{R}=\mathrm{H}: 90 \%, 94 \%$ ee

$\mathrm{Ar}=m-\mathrm{Tol}, \mathrm{R}=\mathrm{H}: 98 \%, 99 \%$ ee

$\mathrm{Ar}=p-\mathrm{Tol}, \mathrm{R}=\mathrm{H}: 98 \%, 99 \%$ ee

$\mathrm{Ar}=0-\mathrm{MeOC}_{6} \mathrm{H}_{4}, \mathrm{R}=\mathrm{H}: 98 \%, 98 \%$ ee

$\mathrm{Ar}=m-\mathrm{MeOC}_{6} \mathrm{H}_{4}, \mathrm{R}=\mathrm{H}: 95 \%, 98 \%$ ee

$\mathrm{Ar}=p-\mathrm{MeOC}_{6} \mathrm{H}_{4}, \mathrm{R}=\mathrm{H}: 97 \%, 99 \%$ ee

$\mathrm{Ar}=m-\mathrm{ClC}_{6} \mathrm{H}_{4}, \mathrm{R}=\mathrm{H}: 98 \%, 98 \%$ ee

$\mathrm{Ar}=p-\mathrm{ClC}_{6} \mathrm{H}_{4}, \mathrm{R}=\mathrm{H}: 96 \%, 95 \%$ ee

$\mathrm{Ar}=m-\mathrm{BrC}_{6} \mathrm{H}_{4}, \mathrm{R}=\mathrm{H}: 98 \%, 98 \%$ ee

$\mathrm{Ar}=p-\mathrm{BrC}_{6} \mathrm{H}_{4}, \mathrm{R}=\mathrm{H}: 97 \%, 96 \%$ ee

$\mathrm{Ar}=1-\mathrm{Naph}, \mathrm{R}=\mathrm{H}: \mathbf{7 8 \%}, 93 \%$ ee

$\mathrm{Ar}=2-\mathrm{Naph}, \mathrm{R}=\mathrm{H}: 98 \%$, 98\% ee

$\mathrm{Ar}=2$-thienyl, $\mathrm{R}=\mathrm{H}: 93 \%, 99 \%$ ee

$\mathrm{Ar}=3$-thienyl, $\mathrm{R}=\mathrm{H}: 98 \%, 99 \%$ ee

$\mathrm{Ar}=\left(\mathrm{CH}_{2}\right)_{5}, \mathrm{R}=\mathrm{H}: 93 \%, 95 \%$ ee

Scheme 9: Zinc-catalyzed Mannich reaction of $\mathrm{N}$-Boc-isatin imines with silyl ketene imines.

isatin imines 32 [49]. The process was performed in the presence of $\mathrm{MeONa}, \mathrm{NaI}$ and methanol in THF at $60{ }^{\circ} \mathrm{C}$ to afford the corresponding chiral 3-alkylated 3-amino-2-oxindoles $\mathbf{3 3}$ in most cases in quantitative yields ( 31 to $>99 \%$ ) combined with moderate to good diastereoselectivities (46-88\% de) and enantioselectivities (21-90\% ee), as shown in Scheme 10. The best yields were generally achieved in the reaction of isatin imines exhibiting an electron-withdrawing group $\left(\mathrm{R}^{2}=\mathrm{Br}, \mathrm{F}, \mathrm{Cl}, \mathrm{CF}_{3}\right)$ at the 6-position of the $N$-phenyl group ( $>99 \%$ yield), while a modest yield (73\%) combined with the lowest enantioselectivity $(21 \%$ ee) was obtained in the reaction of an isatin imine bearing an electron-donating group $\left(\mathrm{R}^{2}=\mathrm{OMe}\right)$. Employing a dibromo-substituted isatin imine $\left(\mathrm{R}^{1}=\mathrm{R}^{2}=\mathrm{Br}\right)$ provided the lowest yield (31\%). The authors have proposed that the true catalyst of the reaction was a chiral tin iodide methoxide 34 in situ generated from chiral tin bromide 30, two equivalents of $\mathrm{NaI}$ and $\mathrm{NaOMe}$ (Scheme 10).

\section{Enantioselective aza-Morita-Baylis-Hillman reactions}

The Morita-Baylis-Hillman reaction is a carbon-carbon bondforming reaction occurring between the $\alpha$-position of an activated alkene and a carbon electrophile such as an aldehyde. Employing a nucleophilic organocatalyst [26], such as a tertiary 
<smiles>[R]c1ccc(/N=C2\C(=O)Nc3cc([R])ccc32)cc1</smiles>

$32 \mathrm{Bn}$

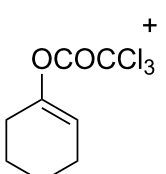<smiles>Br[Sn]Cc1c(Br)cc2ccccc2c1-c1c(Br)c(Br)cc2ccccc12</smiles>

$30(5 \mathrm{~mol} \%)$

$\mathrm{Ar}=p-(t-\mathrm{Bu}) \mathrm{C}_{6} \mathrm{H}_{4}$

$\mathrm{NaOMe}(5 \mathrm{~mol} \%)$

$\mathrm{Nal}(10 \mathrm{~mol} \%)$

$\mathrm{MeOH}$ (10 equiv)

$\mathrm{THF}, 60^{\circ} \mathrm{C}$<smiles>[R]c1ccc(CN2C(=O)C(Nc3ccc([R])cc3)(C3CCCCC3=O)c3ccc([R])cc32)cc1</smiles>

33

31

$\mathrm{R}^{1}=\mathrm{H}, \mathrm{R}^{2}=\mathrm{Br}:>99 \%, 80 \%$ de, $90 \%$ ee

$\mathrm{R}^{1}=\mathrm{H}, \mathrm{R}^{2}=\mathrm{F}:>99 \%, 84 \%$ de, $52 \%$ ee

$\mathrm{R}^{1}=\mathrm{H}, \mathrm{R}^{2}=\mathrm{Cl}:>99 \%, 46 \%$ de, $46 \%$ ee

$\mathrm{R}^{1}=\mathrm{H}, \mathrm{R}^{2}=\mathrm{CF}_{3}:>99 \%, 48 \%$ de, $67 \%$ ee

$R^{1}=H, R^{2}=M e:>99 \%, 88 \%$ de, $59 \%$ ee

$R^{1}=H, R^{2}=$ OMe: $73 \%, 58 \%$ de, $21 \%$ ee

$\mathrm{R}^{1}=\mathrm{R}^{2}=\mathrm{Br}: 31 \%, 52 \%$ de, $59 \%$ ee

in situ formation of the true catalyst $\mathbf{3 4}$ :<smiles>Brc1cc2ccccc2cc1-c1c(C[Sn](Br)Br)c(Br)cc2ccccc12</smiles>

30

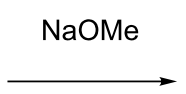

Nal (2 equiv)<smiles>Brc1cc2ccccc2c(-c2c(C[Sn](I)(I)I)c(Br)cc3ccccc23)c1Br</smiles><smiles>CO[Sn](I)(I)Cc1c(Br)cc2ccccc2c1-c1cc2ccccc2cc1Br</smiles>

34

Scheme 10: Tin-catalyzed Mannich reaction of $N$-arylisatin imines with an alkenyl trichloroacetate.

amine or a phosphine, this simple reaction provides densely functionalized products, such as $\alpha$-methylene- $\beta$-hydroxycarbonyl compounds [50-56]. The aza-variant of this process consists in using an activated imine instead of an aldehyde, thus affording $\alpha$-methylene- $\beta$-aminocarbonyl derivatives. In 2015, Takizawa et al. developed enantioselective azaMorita-Baylis-Hillman reactions of $N$-Boc-isatin imines 3 with acrolein (35) promoted by $15 \mathrm{~mol} \%$ of $\beta$-isocupreidine at
$-40{ }^{\circ} \mathrm{C}$ in a 1:1 mixture of toluene and CPME as solvent [57]. As shown in Scheme 11, the corresponding chiral 3-amino-2oxindoles 36 were synthesized with uniformly excellent enantioselectivities (95-98\% ee) and moderate to good yields (48-83\%). Generally, the highest yields (68-83\%) were achieved in the reactions of $N$-benzylisatin imines $\left(\mathrm{R}^{2}=\mathrm{Bn}\right)$ while $N$-allyl, $N$-phenyl and $N$-prenyl-substituted ones led to the corresponding products in $48-70 \%$ yields. 
<smiles>[R]N1C(=O)C(=NC(=O)OC)c2cc[R1]cc21</smiles>

35

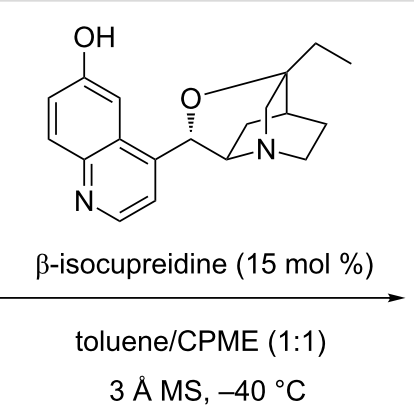

$R^{1}=H, R^{2}=B n: 81 \%, 97 \%$ ee

$\mathrm{R}^{1}=\mathrm{H}, \mathrm{R}^{2}=$ allyl: $70 \%, 96 \%$ ee

$\mathrm{R}^{1}=\mathrm{H}, \mathrm{R}^{2}=\mathrm{Ph}: 52 \%, 98 \%$ ee

$\mathrm{R}^{1}=\mathrm{H}, \mathrm{R}^{2}=$ prenyl: $48 \%, 95 \%$ ee

$R^{1}=5-C l, R^{2}=B n: 68 \%, 98 \%$ ee

$\mathrm{R}^{1}=6-\mathrm{Cl}, \mathrm{R}^{2}=\mathrm{Bn}: 83 \%$, $98 \%$ ee

$R^{1}=7-\mathrm{Cl}, \mathrm{R}^{2}=\mathrm{Bn}: 81 \%, 97 \%$ ee

$R^{1}=5-B r, R^{2}=B n: 73 \%, 96 \%$ ee

$\mathrm{R}^{1}=5-\mathrm{F}, \mathrm{R}^{2}=\mathrm{Bn}: 78 \%, 98 \%$ ee

$R^{1}=5-M e, R^{2}=B n: 77 \%, 95 \%$ ee

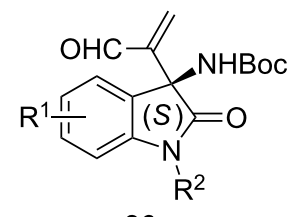

36

Scheme 11: Aza-Morita-Baylis-Hillman reaction of $N$-Boc-isatin imines with acrolein catalyzed by $\beta$-isocupreidine.

Interestingly, the authors found that using $20 \mathrm{~mol} \%$ of $\alpha$-isocupreine as organocatalyst instead of $15 \mathrm{~mol} \%$ of $\beta$-isocupreidine (Scheme 11) in this reaction resulted in the formation of the corresponding $(R)$-configured products ent-36 with good to high enantioselectivities ( $83-95 \%$ ee) and moderate to good yields (37-79\%), as shown in Scheme 12. The stereoselectivity of these processes (Scheme 11 and Scheme 12) can be explained by the favored transition states proposed in Scheme 12 based on the fact that the proton transfer constitutes the rate-determining step in the aza-Morita-Baylis-Hillman reaction [58-60]. Indeed, in these favored transition states, the proton shift mediated by the organocatalyst occurred with the least steric hindrance between the quinuclidine moiety of the catalyst and the aromatic ring of the isatin imine.

The same year, Chimni et al. reported organocatalyzed azaMorita-Baylis-Hillman reactions of $N$-Boc-isatin imines 3 with maleimides 37 using $\beta$-isocupreidine as catalyst [61]. It must be noted that maleimides as Morita-Baylis-Hillman donors were challenging in these reactions since they are more usually employed as Michael acceptors. As shown in Scheme 13, a wide variety of chiral 3-amino-2-oxindoles $\mathbf{3 8}$ was synthesized in moderate to good yields $(30-79 \%)$ and enantioselectivities (70-99\% ee). The protocol was compatible to differently substituted isatin imines and maleimide derivatives. In particular, uniformly excellent enantioselectivities (90-99\% ee) were achieved in the reaction of $N$-phenylmaleimide $\left(\mathrm{R}^{3}=\mathrm{Ph}\right)$ with a range of isatin imines bearing various substituents. However lower levels of enantioselectivity $(70-76 \%$ ee) were obtained in the reactions of $N$-benzyl $\left(\mathrm{R}^{3}=\mathrm{Bn}\right), N$-methyl $\left(\mathrm{R}^{3}=\mathrm{Me}\right), N-2$ phenylethyl $\left(\mathrm{R}^{3}=\mathrm{CH}_{2} \mathrm{Bn}\right)$ and $N$-2-(2-naphthyl)ethyl $\left(\mathrm{R}^{3}=\mathrm{CH}_{2}(2-\mathrm{Naph})\right)$ maleimides.

In 2017, Khan et al. reported the first asymmetric organocatalytic synthesis of chiral 3-amino-2-oxindoles based on enantioselective aza-Morita-Baylis-Hillman reaction of $N$-Boc-isatin imines 3 with activated nitroolefins 39 [62]. The best results were achieved by using cinchona alkaloid-derived thiourea catalyst 40 in toluene at $-10{ }^{\circ} \mathrm{C}$. Indeed, in the presence of only $2.5 \mathrm{~mol} \%$ of this quinine-derived organocatalyst, the reaction afforded a range of chiral densely functionalized azaMorita-Baylis-Hillman products $\mathbf{4 1}$ in good to high yields (65-88\%), high diastereoselectivities (90-98\% de) and moderate to high enantioselectivities (54-94\% ee), as shown in Scheme 14. Various electron-donating and electron-withdrawing groups $\left(\mathrm{R}^{1}\right)$ were tolerated on the aryl moiety of the isatin imines, providing good to high yields $(68-88 \%)$ and enantioselectivities (72-94\% ee). On the other hand, the lowest yield $(65 \%)$ and enantioselectivity (54\% ee) were obtained in the reaction of the $N$-benzyl 5 -Br substituted substrate $\left(\mathrm{R}^{1}=5-\mathrm{Br}, \mathrm{R}^{2}=\mathrm{Bn}\right)$.

\section{Enantioselective Friedel-Crafts reactions}

The Friedel-Crafts reaction is widely employed in total synthesis [63-65]. In 2015, Pedro et al. reported the first asymmetric Friedel-Crafts reaction of $N$-Boc-isatin imines 3 with naphthols performed in the presence of cinchona alkaloid-derived thiourea 40 [66]. As shown in Scheme 15, the reaction of 1-naph- 


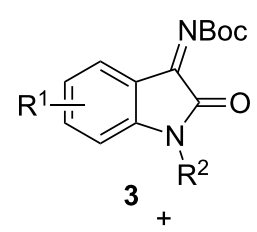

$\gtrsim \mathrm{CHO}$

35

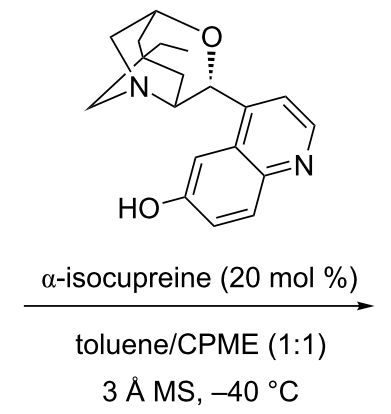

$\mathrm{R}^{1}=\mathrm{H}, \mathrm{R}^{2}=\mathrm{Bn}: 78 \%, 95 \%$ ee

$R^{1}=H, R^{2}=$ allyl: $59 \%, 90 \%$ ee

$\mathrm{R}^{1}=\mathrm{H}, \mathrm{R}^{2}=\mathrm{Ph}: 37 \%, 87 \%$ ee

$\mathrm{R}^{1}=\mathrm{H}, \mathrm{R}^{2}=$ prenyl: $44 \%, 89 \%$ ee

$\mathrm{R}^{1}=5-\mathrm{Cl}, \mathrm{R}^{2}=\mathrm{Bn}: 74 \%, 87 \%$ ee

$R^{1}=7-C l, R^{2}=B n: 44 \%, 94 \%$ ee

$R^{1}=5-B r, R^{2}=B n: 79 \%, 88 \%$ ee

$R^{1}=5-M e, R^{2}=B n: 58 \%, 83 \%$ ee

$R^{1}=H, R^{2}=$ Me: $45 \%, 83 \%$ ee

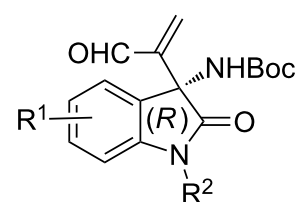

ent-36

plausible transition states for Scheme 9 and Scheme 10:

with $\beta$-isocupreidine:

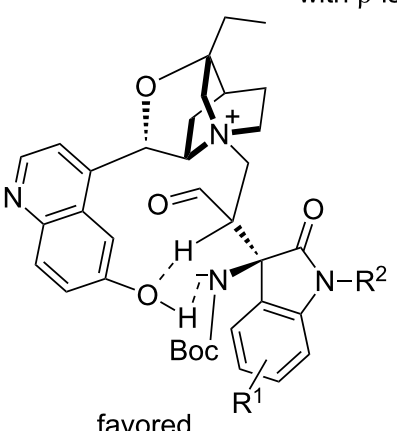

favored

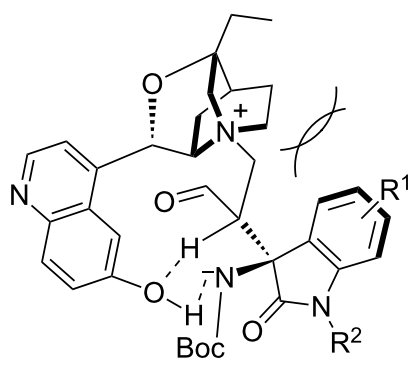

disfavored

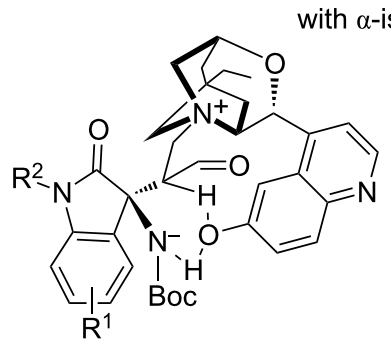

favored

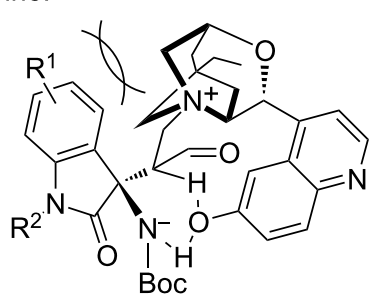

disfavored

Scheme 12: Aza-Morita-Baylis-Hillman reaction of $\mathrm{N}$-Boc-isatin imines with acrolein (35) catalyzed by a-isocupreine.

thols 42 promoted by $2 \mathrm{~mol} \%$ of this bifunctional catalyst in toluene at room temperature led to the corresponding chiral 3-substituted 3-amino-2-oxindoles $\mathbf{4 3}$ in good to high yields $(78-99 \%)$ and uniformly excellent enantioselectivities (94-99\% ee) regardless of the electronic character of the aromatic rings of the isatin and 1-naphthol and the position of their substituent $\left(\mathrm{R}^{1}\right.$ and $\left.\mathrm{R}^{2}\right)$. Moreover, comparable excellent yields (90-97\%) and enantioselectivities (96-99\% ee) were achieved with variously $N$-alkyl substituted isatin imines $\left(\mathrm{R}^{3}=\mathrm{Bn}\right.$, allyl, $\mathrm{Me}, \mathrm{MOM})$. The scope of this unprecedented methodology was extended to 2-naphthols 44 which required $10 \mathrm{~mol} \%$ of catalyst loading to provide the optimal results. In these conditions, the reaction with a range of variously substituted $N$-Boc-isatin imines 3 provided the corresponding products 45 in comparable yields (85-99\%) and moderate to excellent enantioselectivities $(75-99 \%$ ee), as illustrated in Scheme 15 . A variety of 
<smiles>[R]c1ccc2c(c1)C(=N[R16]([H])(C)[O-])C(=O)N2</smiles>

$3 \mathrm{R}^{1}$<smiles>[R]N1C(=O)C=CC1=O</smiles>

37 $\beta$-isocupreidine (20 mol \%)

\section{$4 \AA \mathrm{MS}$}

$\mathrm{CHCl}_{3}$, it

$\mathrm{R}^{1}=\mathrm{Bn}, \mathrm{R}^{2}=\mathrm{H}, \mathrm{R}^{3}=\mathrm{Ph}: 55 \%, 95 \%$ ee

$R^{1}=B n, R^{2}=F, R^{3}=P h: 66 \%, 96 \%$ ee

$R^{1}=B n, R^{2}=C l, R^{3}=P h: 75 \%, 96 \%$ ee

$R^{1}=B n, R^{2}=B r, R^{3}=P h: 57 \%, 96 \%$ ee

$R^{1}=B n, R^{2}=I, R^{3}=P h: 76 \%, 99 \%$ ee

$R^{1}=B n, R^{2}=$ OMe, $R^{3}=P h: 47 \%, 96 \%$ ee

$R^{1}=$ allyl, $R^{2}=H, R^{3}=P h: 58 \%, 95 \%$ ee

$R^{1}=$ allyl, $R^{2}=F, R^{3}=P h: 62 \%, 96 \%$ ee

$\mathrm{R}^{1}=$ allyl, $\mathrm{R}^{2}=\mathrm{Cl}, \mathrm{R}^{3}=\mathrm{Ph}: 66 \%, 95 \%$ ee

$R^{1}=$ allyl, $R^{2}=B r, R^{3}=P h: 46 \%, 95 \%$ ee

$R^{1}=$ allyl, $R^{2}=I, R^{3}=P h: 63 \%, 90 \%$ ee

$\mathrm{R}^{1}=$ allyl, $\mathrm{R}^{2}=\mathrm{OMe}, \mathrm{R}^{3}=\mathrm{Ph}: 35 \%, 95 \%$ ee

$\mathrm{R}^{1}=\mathrm{CH}_{2} \mathrm{C}(\mathrm{Me}) \mathrm{CH}_{2}, \mathrm{R}^{2}=\mathrm{Cl}, \mathrm{R}^{3}=\mathrm{Ph}: 77 \%, 98 \%$ ee

$\mathrm{R}^{1}=\mathrm{MeCH}=\mathrm{CHCH}_{2}, \mathrm{R}^{2}=\mathrm{Cl}, \mathrm{R}^{3}=\mathrm{Ph}: 55 \%, 96 \%$ ee

$R^{1}=R^{3}=P h, R^{2}=H: 75 \%, 92 \%$ ee

$\mathrm{R}^{1}=$ allyl, $\mathrm{R}^{2}=\mathrm{H}, \mathrm{R}^{3}=\mathrm{Bn}: 64 \%, 76 \%$ ee

$R^{1}=$ allyl, $R^{2}=H, R^{3}=$ Me: $30 \%, 71 \%$ ee

$\mathrm{R}^{1}=$ allyl, $\mathrm{R}^{2}=\mathrm{H}, \mathrm{R}^{3}=\mathrm{CH}_{2} \mathrm{Bn}: 76 \%, 70 \%$ ee

$\mathrm{R}^{1}=$ allyl, $\mathrm{R}^{2}=\mathrm{H}, \mathrm{R}^{3}=\mathrm{CH}_{2}$ (2-Naph): $79 \%, 75 \%$ ee

Scheme 13: Aza-Morita-Baylis-Hillman reaction of $N$-Boc-isatin imines with maleimides catalyzed by $\beta$-isocupreidine.<smiles>[R]N1C(=O)C(=NC(C)(C)C)c2cc[R1]cc21</smiles><smiles>CC(=C[N+](=O)[O-])c1ccc[14c](C)c1</smiles>

39<smiles>C=CC1CC2CCC1N2C(NC(=S)NC)c1ccnc2ccc(OC)cc12</smiles>

$40(2.5 \mathrm{~mol} \%)$

$$
\stackrel{\mathrm{Ar}=3,5-\left(\mathrm{CF}_{3}\right)_{2} \mathrm{C}_{6} \mathrm{H}_{3}}{\longrightarrow}
$$

toluene, $-10^{\circ} \mathrm{C}$<smiles>[R]c1ccc2c(c1)C(N)(C1C(=O)C(=O)N([R1])C1=O)C(=O)N2[R1]</smiles>

38 


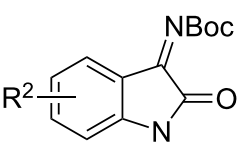

$R^{3}$<smiles>Oc1cccc2cc[R1]cc12</smiles>

42<smiles>CCNC(=S)NC(c1ccnc2ccc(OC)cc12)C1CC2CCN1CC2</smiles>

$40(2 \mathrm{~mol} \%)$

$$
\mathrm{Ar}=3,5-\left(\mathrm{CF}_{3}\right)_{2} \mathrm{C}_{6} \mathrm{H}_{3}
$$

toluene, rt<smiles>[R][R]1ccc2c(c1)[C@](N)(c1ccc3ccccc3c1O)C(=O)N2[R3]</smiles>

43

$R^{1}=R^{2}=H, R^{3}=B n: 93 \%, 99 \%$ ee

$R^{1}=R^{2}=H, R^{3}=$ allyl: $93 \%, 99 \%$ ee

$R^{1}=R^{2}=H, R^{3}=$ Me: $97 \%, 96 \%$ ee

$R^{1}=R^{2}=H, R^{3}=$ MOM: $90 \%, 99 \%$ ee

$R^{1}=H, R^{2}=5-O M e, R^{3}=B n: 95 \%, 99 \%$ ee

$\mathrm{R}^{1}=\mathrm{H}, \mathrm{R}^{2}=5-\mathrm{Cl}, \mathrm{R}^{3}=\mathrm{Bn}: 96 \%, 98 \%$ ee

$R^{1}=H, R^{2}=5-B r, R^{3}=B n: 99 \%, 95 \%$ ee

$\mathrm{R}^{1}=\mathrm{H}, \mathrm{R}^{2}=5-\mathrm{NO}_{2}, \mathrm{R}^{3}=\mathrm{Bn}: 80 \%, 97 \%$ ee

$\mathrm{R}^{1}=\mathrm{H}, \mathrm{R}^{2}=6-\mathrm{Cl}, \mathrm{R}^{3}=\mathrm{Bn}: 97 \%, 99 \%$ ee

$R^{1}=H, R^{2}=7-M e, R^{3}=B n: 95 \%, 99 \%$ ee

$\mathrm{R}^{1}=\mathrm{H}, \mathrm{R}^{2}=7-\mathrm{F}, \mathrm{R}^{3}=\mathrm{Bn}: 80 \%, 99 \%$ ee

$R^{1}=H, R^{2}=5,7-(M e)_{2}, R^{3}=B n: 86 \%, 97 \%$ ee

$\mathrm{R}^{1}=4-\mathrm{Cl}, \mathrm{R}^{2}=\mathrm{H}, \mathrm{R}^{3}=\mathrm{Bn}: 78 \%, 97 \%$ ee

$R^{1}=4-O A c, R^{2}=H, R^{3}=B n: 96 \%, 99 \%$ ee

$\mathrm{R}^{1}=6-\mathrm{OAc}, \mathrm{R}^{2}=\mathrm{H}, \mathrm{R}^{3}=\mathrm{Bn}: 99 \%, 99 \%$ ee

$R^{1}=4-B r, R^{2}=5,7-(M e)_{2}, R^{3}=B n: 93 \%, 94 \%$ ee<smiles>[R][Y10]1ccc2c(c1)C(=N[R16](C)(C)C)C(=O)N2</smiles>

$\mathrm{R}^{3}$<smiles>Oc1ccc2cc[R1]cc2c1</smiles>

44
40 (10 mol \%)

toluene, it<smiles>[R][R]1ccc2c(c1)N([R])C(=O)[C@]2(N)c1c(O)ccc2ccccc12</smiles>

$R^{1}=R^{2}=H, R^{3}=B n: 97 \%, 91 \%$ ee

$R^{1}=R^{2}=H, R^{3}=$ allyl: $99 \%, 89 \%$ ee

$R^{1}=R^{2}=H, R^{3}=$ Me: $90 \%, 75 \%$ ee

$R^{1}=H, R^{2}=5-M e, R^{3}=B n: 85 \%, 90 \%$ ee

$\mathrm{R}^{1}=\mathrm{H}, \mathrm{R}^{2}=5-\mathrm{Cl}, \mathrm{R}^{3}=\mathrm{Bn}: 93 \%, 89 \%$ ee

$R^{1}=H, R^{2}=6-C l, R^{3}=B n: 97 \%, 91 \%$ ee

$R^{1}=3-O M e, R^{2}=H, R^{3}=B n: 82 \%, 99 \%$ ee

$R^{1}=7-\mathrm{OMe}, \mathrm{R}^{2}=\mathrm{H}, \mathrm{R}^{3}=\mathrm{Bn}: 87 \%, 89 \%$ ee

$R^{1}=7-B r, R^{2}=H, R^{3}=B n: 93 \%, 86 \%$ ee

$R^{1}=8-O M e, R^{2}=H, R^{3}=B n: 96 \%, 97 \%$ ee

$\mathrm{R}^{1}=6-\mathrm{CO}_{2} \mathrm{Me}, \mathrm{R}^{2}=\mathrm{H}, \mathrm{R}^{3}=\mathrm{Bn}: 86 \%, 89 \%$ ee

Scheme 15: Friedel-Crafts reactions of $N$-Boc-isatin imines with 1 and 2-naphthols catalyzed by a cinchona alkaloid-derived thiourea

2-naphthols substituted with electron-donating or electron-withdrawing groups were tolerated, giving good results in most cases. The best enantioselectivity $(99 \%$ ee) was achieved in the reaction of 3-methoxy-substituted 2-naphthol whereas the lowest one $(75 \%$ ee) was obtained in the reaction of an $N$-methylisatin imine $\left(\mathrm{R}^{2}=\mathrm{H}, \mathrm{R}^{3}=\mathrm{Me}\right)$ with unsubstituted 2-naphthol $\left(\mathrm{R}^{1}=\mathrm{H}\right)$. It must be noted that these transformat- ions represented the first highly enantioselective additions of naphthols to ketimines.

In 2017, similar reactions were reinvestigated by Tanyeli and Karahan by using the closely related catalyst 8 at $-20{ }^{\circ} \mathrm{C}$ in dichloromethane as the solvent [67]. The products 43 and 46 arisen from the reaction of 1-naphthols $\mathbf{4 2}$ with a range of vari- 
ously substituted $N$-alkoxycarbonylisatin imines 3 and $\mathbf{9}$ were obtained in moderate to quantitative yields (61-99\%) and excellent enantioselectivities ( 92 to $>99 \%$ ee) in most cases. Only two substrates, such as a disubstituted $N$-Boc-isatin imine $\left(\mathrm{R}^{1}=5,7-\mathrm{Me}_{2}, \mathrm{R}^{2}=\mathrm{H}\right)$ and an $N$-acetylated one $\left(\mathrm{R}^{1}=\mathrm{H}\right.$, $\mathrm{R}^{2}=\mathrm{Ac}$ ), afforded the products in much lower enantioselectivities of $37 \%$ and $3 \%$ ee, respectively. On the other hand, products $\mathbf{4 5}$ and $\mathbf{4 7}$ arisen from the reaction of 2-naphthols $\mathbf{4 4}$ with
$\mathrm{N}$-alkoxycarbonylisatin imines $\mathbf{3}$ and $\mathbf{9}$ were formed in moderate to excellent enantioselectivities (54-97\% ee) combined with good to quantitative yields (76-99\%), as shown in Scheme 16. It must be noted that both reactions involving 1 and 2-naphthols employed only $2 \mathrm{~mol} \%$ of catalyst loading.

Very recently, Pedro and Vila reported the enantioselective Friedel-Crafts reaction of $\mathrm{N}$-Boc-isatin imines 3 with<smiles>[R9]C(=O)/N=C1/C(=O)Nc2cc[R1]cc21</smiles>

3, $9 \stackrel{1}{R}^{2}$

$\mathrm{OH}$<smiles>Oc1cccc2ccccc12</smiles>

42<smiles>[R9]C(=O)/N=C1/C(=O)Nc2c[R17]cc21</smiles>

$3,9 \mathrm{R}^{2}$

$+$<smiles>Oc1ccc2ccccc2c1</smiles>

44<smiles>[R]Nc1c(NC(c2ccnc3ccc(OC)cc23)C2CC3CCN2CC3)c(=O)c1=O</smiles>

$8(2 \mathrm{~mol} \%)$

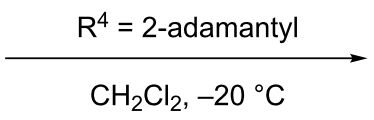

$4 \AA \mathrm{MS}$

$\mathrm{R}^{1}=\mathrm{R}^{2}=\mathrm{H}, \mathrm{R}^{3}=t-\mathrm{Bu}: 99 \%, 97 \%$ ee

$R^{1}=R^{2}=H, R^{3}=B n: 76 \%, 98 \%$ ee

$\mathrm{R}^{1}=\mathrm{R}^{2}=\mathrm{H}, \mathrm{R}^{3}=\mathrm{CO}_{2} \mathrm{Et}: 80 \%, 99 \%$ ee

$\mathrm{R}^{1}=\mathrm{H}, \mathrm{R}^{2}=\mathrm{Et}, \mathrm{R}^{3}=t-\mathrm{Bu}: 61 \%, 94 \%$ ee

$R^{1}=H, R^{2}=B n, R^{3}=t-B u: 99 \%, 99 \%$ ee

$R^{1}=H, R^{2}=$ Me, $R^{3}=t-B u: 99 \%, 99 \%$ ee

$\mathrm{R}^{1}=\mathrm{H}, \mathrm{R}^{2}=\mathrm{Ac}, \mathrm{R}^{3}=t-\mathrm{Bu}: 78 \%, 3 \%$ ee

$R^{1}=5,7-M_{2}, R^{2}=H, R^{3}=t-B u: 98 \%, 37 \%$ ee

$R^{1}=5-B r, R^{2}=H, R^{3}=t-B u: 73 \%, 97 \%$ ee

$\mathrm{R}^{1}=5-\mathrm{F}, \mathrm{R}^{2}=\mathrm{H}, \mathrm{R}^{3}=t-\mathrm{Bu}: 67 \%, 92 \%$ ee

$R^{1}=H, R^{2}=M e, R^{3}=B n: 94 \%,>99 \%$ ee

$\mathrm{R}^{1}=\mathrm{H}, \mathrm{R}^{2}=\mathrm{Me}, \mathrm{R}^{3}=\mathrm{CO}_{2} \mathrm{Et}: 99 \%, 97 \%$ ee

$\mathrm{R}^{1}=5-\mathrm{Me}, \mathrm{R}^{2}=\mathrm{Me}, \mathrm{R}^{3}=t-\mathrm{Bu}: 98 \%, 97 \%$ ee

$\mathrm{R}^{1}=7-\mathrm{F}, \mathrm{R}^{2}=\mathrm{Me}, \mathrm{R}^{3}=t-\mathrm{Bu}: 94 \%,>99 \%$ ee

$\mathrm{R}^{1}=6-\mathrm{Br}, \mathrm{R}^{2}=\mathrm{Me}, \mathrm{R}^{3}=t-\mathrm{Bu}: 70 \%, 99 \%$ ee

$\mathrm{R}^{1}=7-\mathrm{Cl}, \mathrm{R}^{2}=\mathrm{Me}, \mathrm{R}^{3}=t-\mathrm{Bu}: 90 \%, 94 \%$ ee

$\mathrm{R}^{1}=5-\mathrm{OMe}, \mathrm{R}^{2}=\mathrm{Me}, \mathrm{R}^{3}=t-\mathrm{Bu}: 99 \%, 98 \%$ ee

$\mathrm{R}^{1}=6-\mathrm{Cl}, \mathrm{R}^{2}=\mathrm{Me}, \mathrm{R}^{3}=t-\mathrm{Bu}: 90 \%, 99 \%$ ee
$\mathrm{R}^{1}=\mathrm{H}, \mathrm{R}^{2}=\mathrm{Bn}, \mathrm{R}^{3}=t-\mathrm{Bu}: 99 \%, 97 \%$ ee

$\mathrm{R}^{1}=\mathrm{H}, \mathrm{R}^{2}=\mathrm{Me}, \mathrm{R}^{3}=t-\mathrm{Bu}: 85 \%, 79 \%$ ee

$R^{1}=R^{2}=H, R^{3}=\mathrm{CO}_{2}$ Et: $76 \%, 73 \%$ ee

$\mathrm{R}^{1}=7-\mathrm{F}, \mathrm{R}^{2}=\mathrm{Me}, \mathrm{R}^{3}=t-\mathrm{Bu}: 95 \%, 95 \%$ ee

$\mathrm{R}^{1}=5-\mathrm{OMe}, \mathrm{R}^{2}=\mathrm{Me}, \mathrm{R}^{3}=t-\mathrm{Bu}: 86 \%, 85 \%$ ee

$\mathrm{R}^{1}=7-\mathrm{Cl}, \mathrm{R}^{2}=\mathrm{Me}, \mathrm{R}^{3}=t-\mathrm{Bu}: 97 \%, 91 \%$ ee

$R^{1}=5-M e, R^{2}=M e, R^{3}=t-B u: 98 \%, 54 \%$ ee<smiles>[R10]CN[C@]1(c2cc3ccccc3cc2O)C(=O)N([R])c2cc[R1]cc21</smiles>

43, 46 
6-hydroxyquinolines 48 promoted by the cinchona alkaloidderived thiourea 40 [68]. The process was performed in toluene at room temperature to give the corresponding chiral 3-amino2-oxindoles 49 bearing a quinoline moiety in moderate to excellent yields (46-98\%) and uniformly excellent enantioselectivities (94-98\% ee), as shown in Scheme 17. Comparable results were achieved for $N$-benzyl, $N$-phenyl, $N$-allyl and $N$-methylsubstituted isatin imines $\left(\mathrm{R}^{3}=\mathrm{Bn}, \mathrm{Ph}\right.$, allyl, Me). Moreover, various electron-donating or electron-withdrawing groups were tolerated at the 5, 6 or 7-position of the isatin aryl moiety $\left(\mathrm{R}^{2}\right)$. The lowest yield (46\%) was obtained in the reaction of a disubstituted ketimine $\left(\mathrm{R}^{2}=5,7-\mathrm{Me}_{2}\right)$. It must be noted that this methodology represented the first enantioselective addition of hydroxyquinolines to imines.

\section{Enantioselective aza-Henry reactions}

The catalytic asymmetric Henry reaction, also known as catalytic asymmetric nitroaldol reaction, constitutes a useful synthetic methodology towards chiral $\beta$-nitro alcohols $[69,70]$. This reaction and related aza-Henry reactions involving imines have been promoted by both metal catalysts and organocatalysts. While isatins have been widely used as substrates in asymmetric Henry reactions, isatin imines have been less explored as aza-
Henry acceptors in enantioselective reactions. Recently, several groups have developed enantioselective aza-Henry reactions of isatin imines catalyzed by either chiral organocatalysts or chiral metal complexes. Among the organocatalysts, chiral bifunctional guanidine $\mathbf{5 0}$ was applied by Feng et al. in 2015 to promote the reaction of nitromethane $\mathbf{5 1}$ with $N$-Boc-isatin imines 3 (Scheme 18) [71]. The reaction performed at $-30{ }^{\circ} \mathrm{C}$ using $10 \mathrm{~mol} \%$ of this catalyst in toluene provided a range of chiral aza-Henry products $\mathbf{5 2}$ in high to quantitative yields (81-99\%) and high enantioselectivities (86-94\% ee). Generally, $N$-benzyl-substituted isatin imines $\left(\mathrm{R}^{1}=\mathrm{Bn}\right)$ provided better yields (89-99\%) and enantioselectivities (89-94\% ee) than an $N$-methyl-substituted isatin imine ( $81 \%$ yield, $86 \%$ ee with $\left.\mathrm{R}^{1}=\mathrm{Me}, \mathrm{R}^{2}=\mathrm{H}\right)$.

\section{Domino reactions}

In the last decade, a number of highly enantioselective domino processes [72-74] catalyzed by either chiral organocatalysts [26] or chiral metals have been published [75-77]. In 2016, Li and Li reported an efficient asymmetric formal [3+2] annulation reaction between $N$-Boc-isatin imines 3 and 1,4-dithiane2,5-diol (53) as equal equivalent of 2-mercaptoacetaldehyde [78]. The domino reaction catalyzed by chiral tertiary amine-

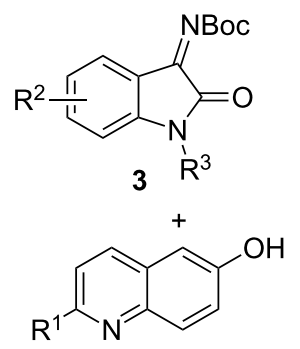

48

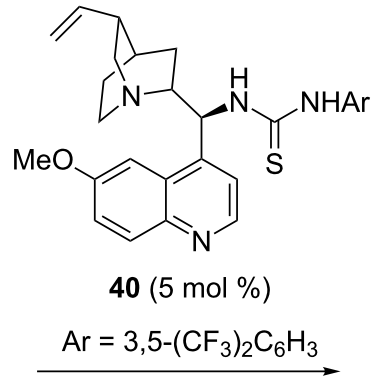

toluene, rt

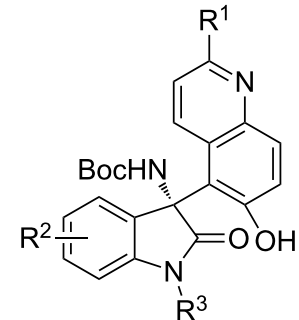

49

$$
\begin{aligned}
& \mathrm{R}^{1}=\mathrm{R}^{2}=\mathrm{H}, \mathrm{R}^{3}=\mathrm{Bn}: 96 \%, 98 \% \text { ee } \\
& \mathrm{R}^{1}=\mathrm{R}^{2}=\mathrm{H}, \mathrm{R}^{3}=\mathrm{Ph}: 73 \%, 94 \% \text { ee } \\
& \mathrm{R}^{1}=\mathrm{R}^{2}=\mathrm{H}, \mathrm{R}^{3}=\text { allyl: } 65 \%, 95 \% \text { ee } \\
& \mathrm{R}^{1}=\mathrm{R}^{2}=\mathrm{H}, \mathrm{R}^{3}=\mathrm{Me}: 77 \%, 95 \% \text { ee } \\
& \mathrm{R}^{1}=\mathrm{H}, \mathrm{R}^{2}=5-\mathrm{Me}, \mathrm{R}^{3}=\mathrm{Bn}: 75 \%, 97 \% \text { ee } \\
& \mathrm{R}^{1}=\mathrm{H}, \mathrm{R}^{2}=5-\mathrm{Me}, \mathrm{R}^{3}=\mathrm{Bn}: 60 \%, 95 \% \text { ee } \\
& \mathrm{R}^{1}=\mathrm{H}, \mathrm{R}^{2}=5-\mathrm{NO}, \mathrm{R}^{3}=\mathrm{Bn}: 75 \%, 96 \% \text { ee } \\
& \mathrm{R}^{1}=\mathrm{H}, \mathrm{R}^{2}=5-\mathrm{Cl}, \mathrm{R}^{3}=\mathrm{Bn}: 98 \%, 96 \% \text { ee } \\
& \mathrm{R}^{1}=\mathrm{H}, \mathrm{R}^{2}=6-\mathrm{Cl}, \mathrm{R}^{3}=\mathrm{Bn}: 84 \%, 96 \% \text { ee } \\
& \mathrm{R}^{1}=\mathrm{H}, \mathrm{R}^{2}=7-\mathrm{F}, \mathrm{R}^{3}=\mathrm{Bn}: 90 \%, 97 \% \text { ee } \\
& \mathrm{R}^{1}=\mathrm{H}, \mathrm{R}^{2}=5,7-\mathrm{Me}_{2}, \mathrm{R}^{3}=\mathrm{Bn}: 46 \%, 97 \% \text { ee } \\
& \mathrm{R}^{1}=6-\mathrm{Me}, \mathrm{R}^{2}=\mathrm{H}, \mathrm{R}^{3}=\mathrm{Bn}: 96 \%, 98 \% \text { ee }
\end{aligned}
$$




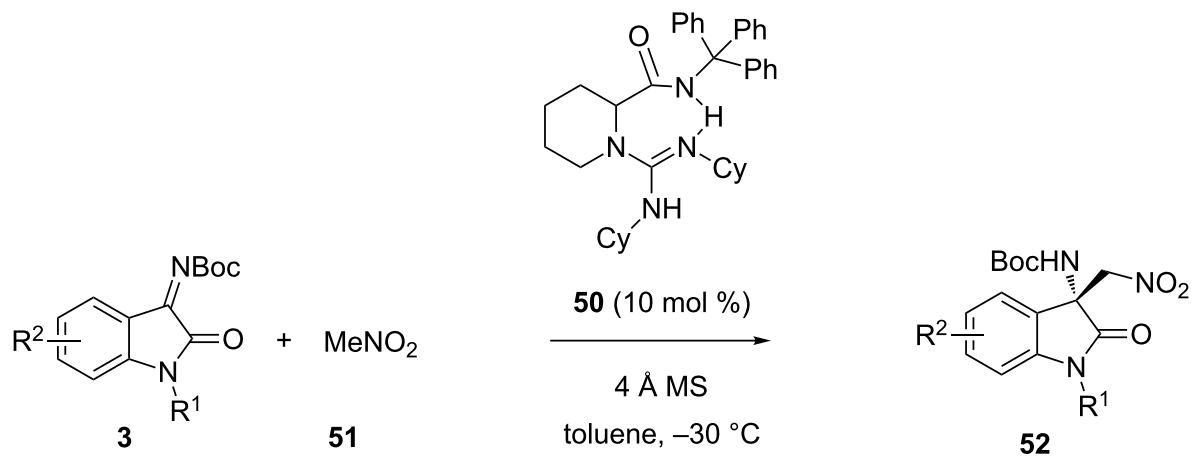

$$
\begin{aligned}
& R^{1}=B n, R^{2}=H: 99 \%, 94 \% \text { ee } \\
& R^{1}=M e, R^{2}=H: 81 \%, 86 \% \text { ee } \\
& R^{1}=B n, R^{2}=5-F: 98 \%, 92 \% \text { ee } \\
& R^{1}=B n, R^{2}=5-C l: 99 \%, 91 \% \text { ee } \\
& R^{1}=B n, R^{2}=5-B r: 98 \%, 91 \% \text { ee } \\
& R^{1}=B n, R^{2}=5-I: 99 \%, 90 \% \text { ee } \\
& R^{1}=B n, R^{2}=5-O C F_{3}: 95 \%, 90 \% \text { ee } \\
& R^{1}=B n, R^{2}=5-M e: 99 \%, 92 \% \text { ee } \\
& R^{1}=B n, R^{2}=6-C l: 98 \%, 94 \% \text { ee } \\
& R^{1}=B n, R^{2}=6-B r: 96 \%, 93 \% \text { ee } \\
& R^{1}=B n, R^{2}=7-F: 99 \%, 93 \% \text { ee } \\
& R^{1}=B n, R^{2}=7-C l: 94 \%, 89 \% \text { ee } \\
& R^{1}=B n, R^{2}=7-B r: 99 \%, 90 \% \text { ee } \\
& R^{1}=B n, R^{2}=7-C F_{3}: 94 \%, 89 \% \text { ee } \\
& R^{1}=B n, R^{2}=5,7-M_{2}: 89 \%, 89 \% \text { ee }
\end{aligned}
$$

Scheme 18: Aza-Henry reaction of $N$-Boc-isatin imines with nitromethane catalyzed by a bifunctional guanidine.

squaramide catalyst $\mathbf{5 4}$ began with the addition of 2-mercaptoacetaldehyde to isatin imine $\mathbf{3}$, leading to an aldehyde intermediate which subsequently cyclized into the corresponding chiral spirocyclic 3-aminooxindole 55. As shown in Scheme 19, a range of these products was achieved in good to high yields (75-95\%) and enantioselectivities (78-97\% ee) combined with low to good diastereoselectivities ( $34-80 \%$ de). The lowest diastereoselectivity $(34 \%$ de) was obtained in the reaction of a disubstituted substrate $\left(\mathrm{R}^{1}=4,7-\mathrm{Cl}_{2}\right)$, showing that it was sensitive to the substitution of the aryl moiety of the isatin. In fact higher diastereoselectivities ( $\geq 60 \%$ de) were achieved for all other substrates variously substituted with electron-donating or electron-withdrawing groups $\left(\mathrm{R}^{1}\right)$. In addition to $N$-benzylsubstituted isatin imines $\left(\mathrm{R}^{2}=\mathrm{Bn}\right)$, the reaction conditions could be applied to a range of $N$-substituted benzyl substrates which all provided the products in comparable high yields (75-95\%) and enantioselectivities (94-97\% ee) along with moderate to good diastereoselectivities (60-78\% de). Furthermore, an $N$-phenylisatin imine $\left(\mathrm{R}^{2}=\mathrm{Ph}, \mathrm{R}^{1}=\mathrm{H}\right)$ was found to smoothly undergo the reaction with excellent results $(91 \%$ yield, $80 \%$ de, $90 \%$ ee).

\section{Miscellaneous reactions}

In 2015, Arai et al. applied a chiral metal complex to promote the enantioselective addition of methanol to $N$-Boc-isatin imines 3 [79]. As shown in Scheme 20, the use of a chiral nickel catalyst in situ generated from $\mathrm{NiCl}_{2}$ and the chiral bis(imidazolidine)pyridine ligand $\mathbf{5 6}$ promoted this reaction in toluene at room temperature in the presence of a base, such as DIPEA, and led to chiral isatin-derived $N, O$-acetals $\mathbf{5 7}$ in good to quantitative yields (69-99\%) and good to high enantioselectivities (78-90\% ee). Notably, generally excellent yields (93-99\%) were obtained in the reactions of variously substituted substrates while the lowest yield of $69 \%$ was observed for the 5-fluorinated isatin imine $(\mathrm{R}=\mathrm{F})$. Comparable reaction conditions were applied to the addition of cumene hydroperoxide 58 to $N$-Boc-isatin imines 3 providing the corresponding chiral oxindoles 59 in even higher yields (99\%) and enantioselectivities (88-94\% ee), as shown in Scheme 20.

In 2016, Zhang and Yang reported an asymmetric palladiumcatalyzed addition of arylboronic acids $\mathbf{6 0}$ to sterically hindered $N$-tert-butylsulfonylisatin imines 61 [80]. Among a variety of 
<smiles>[R]N1C(=C)C(=N)c2cc[R17]cc21</smiles><smiles>CC1CSC(O)CS1</smiles>

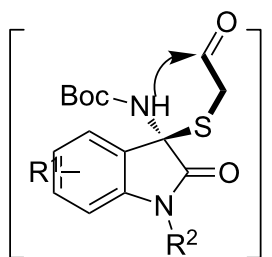<smiles>CNc1c(NC(c2ccccc2)c2ccccc2)c(=O)c1=O</smiles>

54 (1 $\mathrm{mol} \%)$

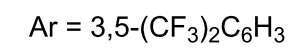
$3 \AA \mathrm{MS}$ $\mathrm{CH}_{2} \mathrm{Cl}_{2}, 0^{\circ} \mathrm{C}$

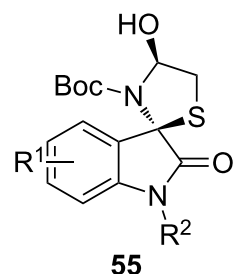

cyclization

$$
\begin{aligned}
& \mathrm{R}^{1}=\mathrm{H}, \mathrm{R}^{2}=\mathrm{Bn}: 92 \%, 72 \% \text { de, } 96 \% \text { ee } \\
& R^{1}=5-M e, R^{2}=B n: 95 \%, 72 \% \text { de, } 94 \% \text { ee } \\
& R^{1}=5-\mathrm{OMe}, \mathrm{R}^{2}=\mathrm{Bn}: 88 \%, 72 \% \text { de, } 92 \% \text { ee } \\
& R^{1}=5-F, R^{2}=B n: 90 \%, 66 \% \text { de, } 93 \% \text { ee } \\
& \mathrm{R}^{1}=5-\mathrm{Cl}, \mathrm{R}^{2}=\mathrm{Bn}: 78 \%, 60 \% \text { de, } 94 \% \text { ee } \\
& \mathrm{R}^{1}=6-\mathrm{Cl}, \mathrm{R}^{2}=\mathrm{Bn}: 91 \%, 60 \% \text { de, } 93 \% \text { ee } \\
& \mathrm{R}^{1}=7-\mathrm{Cl}, \mathrm{R}^{2}=\mathrm{Bn}: 95 \%, 66 \% \text { de, } 78 \% \text { ee } \\
& R^{1}=4,7-C l_{2}, R^{2}=B n: 78 \%, 34 \% \text { de, } 80 \% \text { ee } \\
& \mathrm{R}^{1}=5-\mathrm{Br}, \mathrm{R}^{2}=\mathrm{Bn}: 75 \%, 66 \% \text { de, } 82 \% \text { ee } \\
& \mathrm{R}^{1}=\mathrm{H}, \mathrm{R}^{2}=p-\mathrm{TolCH}_{2}: 88 \%, 75 \% \text { de, } 96 \% \text { ee } \\
& \mathrm{R}^{1}=\mathrm{H}, \mathrm{R}^{2}=p-(t-\mathrm{Bu}) \mathrm{C}_{6} \mathrm{H}_{4} \mathrm{CH}_{2}: 90 \%, 78 \% \text { de, } 95 \% \text { ee } \\
& \mathrm{R}^{1}=\mathrm{H}, \mathrm{R}^{2}=p-\mathrm{CF}_{3} \mathrm{C}_{6} \mathrm{H}_{4} \mathrm{CH}_{2}: 94 \%, 60 \% \text { de, } 94 \% \text { ee } \\
& \mathrm{R}^{1}=\mathrm{H}, \mathrm{R}^{2}=p-\mathrm{FC}_{6} \mathrm{H}_{4} \mathrm{CH}_{2}: 79 \%, 72 \% \text { de, } 94 \% \text { ee } \\
& \mathrm{R}^{1}=\mathrm{H}, \mathrm{R}^{2}=p-\mathrm{ClC}_{6} \mathrm{H}_{4} \mathrm{CH}_{2}: 95 \%, 66 \% \text { de, } 97 \% \text { ee } \\
& \mathrm{R}^{1}=\mathrm{H}, \mathrm{R}^{2}=p-\mathrm{BrC}_{6} \mathrm{H}_{4} \mathrm{CH}_{2}: 92 \%, 60 \% \text { de, } 97 \% \text { ee } \\
& \mathrm{R}^{1}=\mathrm{H}, \mathrm{R}^{2}=m-\mathrm{FC}_{6} \mathrm{H}_{4} \mathrm{CH}_{2}: 95 \%, 75 \% \text { de, } 95 \% \text { ee } \\
& \mathrm{R}^{1}=\mathrm{H}, \mathrm{R}^{2}=3,4-\mathrm{F}_{2} \mathrm{C}_{6} \mathrm{H}_{3} \mathrm{CH}_{2}: 92 \%, 60 \% \text { de, } 96 \% \text { ee } \\
& R^{1}=H, R^{2}=P h: 91 \%, 80 \% \text { de, } 90 \% \text { ee }
\end{aligned}
$$

Scheme 19: Domino addition/cyclization reaction of $\mathrm{N}$-Boc-isatin imines with 1,4-dithiane-2,5-diol (53) catalyzed by a tertiary amine-squaramide.

chiral ligands investigated, including different pyridineoxazolines, oxazolines and $(R)$-BINAP, the chiral pyridineoxazoline ligand In-Pyrox was found optimal to provide a wide variety of chiral 3-amino-2-oxindoles $\mathbf{6 2}$ in moderate to high yields (51-97\%) and uniformly excellent enantioselectivities (91-98\% ee). As shown in Scheme 21, the reaction performed at $70{ }^{\circ} \mathrm{C}$ in TFE as solvent proceeded well in the presence of various substituents $\left(\mathrm{R}^{1}\right)$ at different positions of the aryl moiety of isatin imines, giving comparable enantioselectivities (91-94\% ee). Moreover, the arylboronic acid scope was also found wide and various para- as well as meta-substi- tuted arylboronic acids reacted smoothly, giving the products in high yields (81-96\%) and enantioselectivities (93-96\% ee). Good yields (82-85\%) and high enantioselectivities (92-96\% ee) were also obtained for disubstituted arylboronic acids. Even a heteroaromatic boronic acid (Ar $=2$-thienyl) was tolerated, providing the corresponding product in excellent enantioselectivity (98\% ee) albeit with moderate yield (51\%). However, no reaction occurred with ortho-substituted substrates. This process constituted the first example of a palladium(II)-catalyzed addition of arylborons to exocyclic ketimines. 


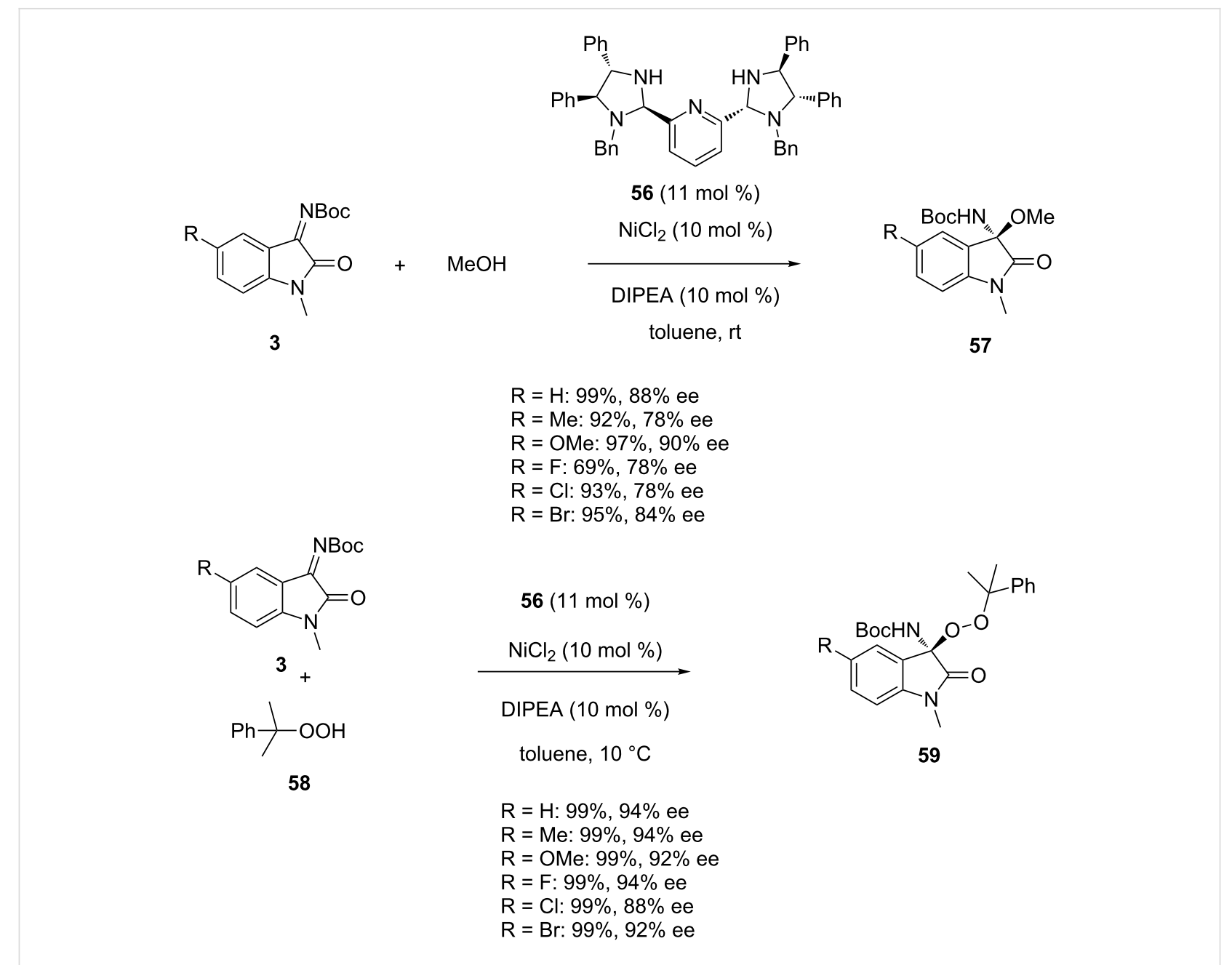

Scheme 20: Nickel-catalyzed additions of methanol and cumene hydroperoxide to $N$-Boc-isatin imines.

\section{Conclusion}

This review demonstrates that much progress has been achieved in the past three years in the field of asymmetric synthesis of 3-substituted 3-amino-2-oxindoles through enantioselective nucleophilic additions to isatin imines, involving both chiral metal and organocatalysts. Indeed, a variety of novel methodologies, including enantioselective Mannich reactions, azaMorita-Baylis-Hilman reactions, Friedel-Crafts reactions, azaHenry reactions, domino reactions, among others have allowed a wide range of these biologically important chiral products to be achieved in generally excellent enantioselectivities and high yields by using different types of metal ligands and organocatalysts. For example, remarkable enantioselectivities of up to 94 to $>99 \%$ ee have been reported in recent examples of Mannich reactions promoted by organocatalysts, as varied as cinchonaalkaloids, squaramides, phosphoric acids, simple primary amines and L-diphenylprolinol trimethylsilyl ether. However, also metal complexes $(\mathrm{Zn}, \mathrm{Sn})$ derived from $N, N$ '-dioxide and BINOL-derived ligands have been employed affording the products with enantioselectivities of up to $90-99 \%$ ee. Moreover, comparable enantioselectivities of up to $99 \%$ ee were reported in aza-Morita-Baylis-Hilman reactions organocatalyzed by cinchona-alkaloids, and unprecedented Friedel-Crafts reactions of isatin imines with naphthols and hydroxyquinolines promoted by cinchona-alkaloid-derived thioureas and cinchonaalkaloid-derived squaramides. Slightly lower enantioselectivity levels of up to $94 \%$ ee were described in aza-Henry reactions performed with bifunctional guanidines. In addition, excellent results $(97 \%$ ee) were reported in unprecedented domino reactions promoted by squaramides recently. Miscellaneous transformations, including additions of methanol, hydroperoxides and arylboronic acids, were also developed with high enantioselectivities (up to $94 \%$ ee) by using chiral nickel and palladium complexes with imidazoline and pyridine-oxazoline ligands while the first additions of enaminones to isatin imines catalyzed by chiral phosphoric acids provided even higher enantioselectivities (up to $97 \%$ ee). In spite of these significant advances, the involvement of other types of organocatalysts and 
<smiles>[R]N1C(=O)/C(=N\OS(C)(C)C)c2cc[R1]([H])cc21</smiles>

$\operatorname{ArB}(\mathrm{OH})_{2}$

60<smiles>c1ccc(C2=N[C@H]3c4ccccc4C[C@H]3O2)nc1</smiles>

In-Pyrox (6 mol \%)

$\operatorname{Pd}(\mathrm{TFA})_{2}(5 \mathrm{~mol} \%)$

TFE, $70^{\circ} \mathrm{C}$

$\mathrm{R}^{2}=2,6-\mathrm{Cl}_{2} \mathrm{C}_{6} \mathrm{H}_{3}$<smiles>[R]N1C(=O)C([AlH2])(NS(=O)(=O)OC(C)(C)C)c2cc[R1]([H])cc21</smiles>

62

$$
\begin{aligned}
& \mathrm{Ar}=\mathrm{Ph}, \mathrm{R}^{1}=\mathrm{H}: 96 \%, 93 \% \text { ee } \\
& \mathrm{Ar}=\mathrm{Ph}, \mathrm{R}^{1}=5-\mathrm{Me}: 96 \%, 92 \% \text { ee } \\
& \mathrm{Ar}=\mathrm{Ph}, \mathrm{R}^{1}=5-\mathrm{OMe}: 97 \%, 93 \% \text { ee } \\
& \mathrm{Ar}=\mathrm{Ph}, \mathrm{R}^{1}=5-\mathrm{F}: 80 \%, 94 \% \text { ee } \\
& \mathrm{Ar}=\mathrm{Ph}, \mathrm{R}^{1}=5-\mathrm{Br}: 71 \%, 93 \% \text { ee } \\
& \mathrm{Ar}=\mathrm{Ph}, \mathrm{R}^{1}=6-\mathrm{Cl}: 95 \%, 94 \% \text { ee } \\
& \mathrm{Ar}=\mathrm{Ph}, \mathrm{R}^{1}=6-\mathrm{Br}: 64 \%, 94 \% \text { ee } \\
& \mathrm{Ar}=\mathrm{Ph}, \mathrm{R}^{1}=7-\mathrm{F}: 96 \%, 91 \% \text { ee } \\
& \mathrm{Ar}=\mathrm{Ph}, \mathrm{R}^{1}=7-\mathrm{Br}: 60 \%, 91 \% \text { ee } \\
& \mathrm{Ar}=p-\mathrm{Tol}, \mathrm{R}^{1}=\mathrm{H}: 93 \%, 94 \% \text { ee } \\
& \mathrm{Ar}=p-(t-\mathrm{Bu}) \mathrm{C}_{6} \mathrm{H}_{4}, \mathrm{R}^{1}=\mathrm{H}: 96 \%, 94 \% \text { ee } \\
& \mathrm{Ar}=p-\mathrm{MeOC}_{6} \mathrm{H}_{4}, \mathrm{R}^{1}=\mathrm{H}: 85 \%, 94 \% \text { ee } \\
& \mathrm{Ar}=p-\mathrm{PhC}_{6} \mathrm{H}_{4}, \mathrm{R}^{1}=\mathrm{H}: 95 \%, 93 \% \text { ee } \\
& \mathrm{Ar}=p-\mathrm{FC}_{6} \mathrm{H}_{4}, \mathrm{R}^{1}=\mathrm{H}: 96 \%, 93 \% \text { ee } \\
& \mathrm{Ar}=p-\mathrm{ClC}_{6} \mathrm{H}_{4}, \mathrm{R}^{1}=\mathrm{H}: 93 \%, 93 \% \text { ee } \\
& \mathrm{Ar}=p-\mathrm{BrC}_{6} \mathrm{H}_{4}, \mathrm{R}^{1}=\mathrm{H}: 81 \%, 93 \% \text { ee } \\
& \mathrm{Ar}=m-\mathrm{Tol}, \mathrm{R}^{1}=\mathrm{H}: 93 \%, 94 \% \text { ee } \\
& \mathrm{Ar}=m-\mathrm{MeOC}_{6} \mathrm{H}_{4}, \mathrm{R}^{1}=\mathrm{H}: 84 \%, 96 \% \text { ee } \\
& \mathrm{Ar}=m-\mathrm{BrC}_{6} \mathrm{H}_{4}, \mathrm{R}^{1}=\mathrm{H}: 82 \%, 93 \% \text { ee } \\
& \mathrm{Ar}=3,5-\mathrm{Me}_{2} \mathrm{C}_{6} \mathrm{H}_{3}, \mathrm{R}^{1}=\mathrm{H}: 82 \%, 92 \% \text { ee } \\
& \mathrm{Ar}=2 \text {-thienyl, } \mathrm{R}^{1}=\mathrm{H}: 51 \%, 98 \% \text { ee } \\
& \mathrm{Ar}=\mathrm{C}_{\mathrm{R}} \mathrm{R}^{1}=\mathrm{H}: 85 \%, 96 \% \text { ee }
\end{aligned}
$$

Scheme 21: Palladium-catalyzed addition of arylboronic acids to $\mathrm{N}$-tert-butylsulfonylisatin imines.

metal ligands will have to be investigated in these transformations along with the use of other nucleophiles to even more extend the library of chiral 3-substituted 3-amino-2-oxindoles available for drug discovery.

\section{ORCID ${ }^{\circledR}$ iDs}

Hélène Pellissier - https://orcid.org/0000-0003-0773-5117

\section{References}

1. Jensen, B. S. CNS Drug Rev. 2002, 8, 353-360. doi:10.1111/j.1527-3458.2002.tb00233.x

2. Dounay, A. B.; Overman, L. E. Chem. Rev. 2003, 103, 2945-2964. doi:10.1021/cr020039h

3. Galliford, C. V.; Scheidt, K. Angew. Chem., Int. Ed. 2007, 46, 8748-8758. doi:10.1002/anie.200701342

4. Singh, G. S.; D'hooghe, M.; De Kimpe, N. Chem. Rev. 2007, 107, 2080-2135. doi:10.1021/cr0680033
5. Singh, G. S.; Desta, Z. Y. Chem. Rev. 2012, 112, 6104-6155. doi:10.1021/cr300135y

6. Hong, L.; Wang, R. Adv. Synth. Catal. 2013, 355, 1023-1052. doi:10.1002/adsc.201200808

7. Trost, B. M.; Bringley, D. A.; Zhang, T.; Cramer, N. J. Am. Chem. Soc. 2013, 135, 16720-16735. doi:10.1021/ja409013m

8. Yu, B.; Yu, D.-Q.; Liu, H.-M. Eur. J. Med. Chem. 2015, 97, 673-698. doi:10.1016/j.ejmech.2014.06.056

9. Zhou, F.; Liu, Y.-L.; Zhou, J. Adv. Synth. Catal. 2010, 352, 1381-1407. doi:10.1002/adsc.201000161

10. Dalpozzo, R.; Bartoli, G.; Bencivenni, G. Chem. Soc. Rev. 2012, 41, 7247-7290. doi:10.1039/c2cs35100e

11. Kumar, A.; Chimni, S. S. RSC Adv. 2012, 2, 9748-9762. doi:10.1039/c2ra21131a

12. Mohammadi, S.; Heiran, R.; Herrera, R. P.; Marqués-López, E. ChemCatChem 2013, 5, 2131-2148. doi:10.1002/cctc.201300050

13. Chauhan, P.; Chimni, S. S. Tetrahedron: Asymmetry 2013, 24 , 343-356. doi:10.1016/j.tetasy.2013.03.002 
14. Liu, Y.-L.; Zhu, F.; Wang, C.; Zhou, J. Chin. J. Org. Chem. 2013, 33, 1595-1615.

15. Yu, J.-S.; Zhou, F.; Liu, Y.-L.; Zhou, J. Synlett 2015, 26, 2491-2504. doi:10.1055/s-0034-1378873

16. Kaur, J.; Chimni, S. S.; Mahajan, S.; Kumar, A. RSC Adv. 2015, 5, 52481-52496. doi:10.1039/C5RA06969F

17. Ziarani, G. M.; Moradi, R.; Lashgari, N. Tetrahedron: Asymmetry 2015, 26, 517-541. doi:10.1016/j.tetasy.2015.04.011

18. Yu, B.; Xing, H.; Yu, D.-Q.; Liu, H.-M. Beilstein J. Org. Chem. 2016, 12, 1000-1039. doi:10.3762/bjoc.12.98

19. Dalpozzo, R. Adv. Synth. Catal. 2017, 359, 1772-1810. doi:10.1002/adsc.201700361

20. Noble, A.; Anderson, J. C. Chem. Rev. 2013, 113, 2887-2939. doi:10.1021/cr300272t

21. Kobayashi, S.; Mori, Y.; Fossey, J. S.; Salter, M. M. Chem. Rev. 2011, 111, 2626-2704. doi:10.1021/cr100204f

22. Marqués-López, E.; Merino, P.; Tejero, T.; Herrera, R. P. Eur. J. Org. Chem. 2009, 2401-2420. doi:10.1002/ejoc.200801097

23. Córdova, A. Acc. Chem. Res. 2004, 37, 102-112. doi:10.1021/ar030231।

24. Marques, M. M. B. Angew. Chem., Int. Ed. 2006, 45, 348-352. doi:10.1002/anie.200502630

25. Candeias, N. R.; Montalbano, F.; Cal, P. M. S. D.; Gois, P. M. P. Chem. Rev. 2010, 110, 6169-6193. doi:10.1021/cr100108k

26. Berkessel, A.; Gröger, H. Asymmetric Organocatalysis-From Biomimetic Concepts to Powerful Methods for Asymmetric Synthesis, Wiley-VCH: Weinheim, 2005. doi:10.1002/3527604677

27. Dalko, P. I., Ed. Enantioselective Organocatalysis; Wiley-VCH: Weinheim, 2007. doi:10.1002/9783527610945

28. Pellissier, H. Tetrahedron 2007, 63, 9267-9331. doi:10.1016/j.tet.2007.06.024

29. Doyle, A. G.; Jacobsen, E. N. Chem. Rev. 2007, 107, 5713-5743. doi:10.1021/cr068373r

30. Dondoni, A.; Massi, A. Angew. Chem., Int. Ed. 2008, 47, 4638-4660. doi:10.1002/anie.200704684

31. Melchiorre, P.; Marigo, M.; Carlone, A.; Bartoli, G. Angew. Chem., Int. Ed. 2008, 47, 6138-6171. doi:10.1002/anie.200705523

32. Palomo, C.; Oiarbide, M.; López, R. Chem. Soc. Rev. 2009, 38, 632-653. doi:10.1039/B708453F

33. Bella, M.; Gasperi, T. Synthesis 2009, 1583-1614. doi:10.1055/s-0029-1216796

34. Pellissier, H. Recent Developments in Asymmetric Organocatalysis; Royal Society of Chemistry: Cambridge, 2010.

35. Zhao, K.; Shu, T.; Jia, J.; Raabe, G.; Enders, D. Chem. - Eur. J. 2015, 21, 3933-3936. doi:10.1002/chem.201406422

36. Rao, K. S.; Ramesh, P.; Chowhan, L. R.; Trivedi, R. RSC Adv. 2016, 6, 84242-84247. doi:10.1039/C6RA16877A

37. Işibol, D.; Karahan, S.; Tanyeli, C. Tetrahedron Lett. 2018, 59, 541-545. doi:10.1016/j.tetlet.2017.12.081

38. Rainoldi, G.; Sacchetti, A.; Silvani, A.; Lesma, G. Org. Biomol. Chem. 2016, 14, 7768-7776. doi:10.1039/C6OB01359G

39. Dai, J.; Xiong, D.; Yuan, T.; Liu, J.; Chen, T.; Shao, Z. Angew. Chem., Int. Ed. 2017, 56, 12697-12701. doi:10.1002/anie.201706304

40. Zhou, L.-J.; Zhang, Y.-C.; Jiang, F.; He, G.; Yan, J.; Lu, H.; Zhang, S.; Shi, F. Adv. Synth. Catal. 2016, 358, 3069-3083. doi:10.1002/adsc.201600508

41. Noyori, R. Asymmetric Catalysts in Organic Synthesis; Wiley: New York, 1994.
42. Beller, M.; Bolm, C., Eds. Transition Metals for Organic Synthesis; Wiley-VCH: Weinheim, 1998; Vol. I and II.

43. Jacobsen, E. N.; Pfaltz, A.; Yamamoto, H., Eds. Comprehensive Asymmetric Catalysis; Springer: Berlin, 1999.

44. Ojima, I., Ed. Catalytic Asymmetric Synthesis, 2nd ed.; Wiley-VCH: New York, 2000.

45. Beller, M.; Bolm, C., Eds. Transition Metals for Organic Synthesis, 2nd ed.; Wiley-VCH: Weinheim, 2004.

46. Tietze, L. F.; Ila, H.; Bell, H. P. Chem. Rev. 2004, 104, 3453-3516. doi:10.1021/cr030700x

47. Ramón, D. J.; Yus, M. Chem. Rev. 2006, 106, 2126-2208. doi:10.1021/cr040698p

48. Zhao, J.; Fang, B.; Luo, W.; Hao, X.; Liu, X.; Lin, L.; Feng, X. Angew. Chem., Int. Ed. 2015, 54, 241-244. doi:10.1002/anie.201408730

49. Yanagisawa, A.; Kushihara, N.; Sugita, T.; Horiguchi, M.; Ida, K.; Yoshida, K. Synlett 2015, 26, 2541-2546. doi:10.1055/s-0035-1560636

50. Basavaiah, D.; Rao, P. D.; Hyma, R. S. Tetrahedron 1996, 52, 8001-8062. doi:10.1016/0040-4020(96)00154-8

51. Basavaiah, D.; Rao, A. J.; Satyanarayana, T. Chem. Rev. 2003, 103 , 811-892. doi:10.1021/cr010043d

52. Declerck, V.; Martinez, J.; Lamaty, F. Chem. Rev. 2009, 109, 1-48. doi:10.1021/cr068057c

53. Basavaiah, D.; Reddy, B. S.; Badsara, S. S. Chem. Rev. 2010, 110, 5447-5674. doi:10.1021/cr900291g

54. Wei, Y.; Shi, M. Chem. Rev. 2013, 113, 6659-6690. doi:10.1021/cr300192h

55. Bhowmik, S.; Batra, S. Curr. Org. Chem. 2014, 18, 3078-3119. doi:10.2174/1385272819666141125003114

56. Xie, P.; Huang, Y. Org. Biomol. Chem. 2015, 13, 8578-8595. doi:10.1039/C5OB00865D

57. Yoshida, Y.; Sako, M.; Kishi, K.; Sasai, H.; Hatakeyama, S.; Takizawa, S. Org. Biomol. Chem. 2015, 13, 9022-9028. doi:10.1039/C5OB00874C

58. Lindner, C.; Liu, Y.; Karaghiosoff, B.; Maryasin, B.; Zipse, H. Chem. - Eur. J. 2013, 19, 6429-6434. doi:10.1002/chem.201204006

59. Verma, P.; Verma, P.; Sunoj, R. B. Org. Biomol. Chem. 2014, 12, 2176-2179. doi:10.1039/c3ob42273a

60. Plata, R. E.; Singleton, D. A. J. Am. Chem. Soc. 2015, 137, 3811-3826. doi:10.1021/ja5111392

61. Kumar, A.; Sharma, V.; Kaur, J.; Kumar, N.; Chimni, S. S. Org. Biomol. Chem. 2015, 13, 5629-5635. doi:10.1039/C5OB00182J

62. Choudhary, M. K.; Menapara, T.; Tak, R.; Kureshy, R. I.; Khan, N.-u. H. ChemistrySelect 2017, 2, 2224-2229. doi:10.1002/slct.201700032

63. You, S.-L.; Cai, Q.; Zeng, M. Chem. Soc. Rev. 2009, 38, 2190-2201. doi:10.1039/b817310a

64. Terrasson, V.; de Figueiredo, R. M.; Campagne, J. M. Eur. J. Org. Chem. 2010, 2635-2655. doi:10.1002/ejoc.200901492

65. Chauhan, P.; Chimni, S. S. RSC Adv. 2012, 2, 6117-6134. doi:10.1039/c2ra20544k

66. Montesinos-Magraner, M.; Vila, C.; Cantón, R.; Blay, G.; Fernández, I.; Muñoz, M. C.; Pedro, J. R. Angew. Chem., Int. Ed. 2015, 54, 6320-6324. doi:10.1002/anie.201501273

67. Karahan, S.; Tanyeli, C. New J. Chem. 2017, 41, 9192-9202. doi:10.1039/C7NJ01395G

68. Vila, C.; Rendón-Patiño, A.; Montesinos-Magraner, M.; Blay, G.; Muñoz, M. C.; Pedro, J. R. Adv. Synth. Catal. 2018, 360, 859-864. doi:10.1002/adsc.201701217 
69. Boruwa, J.; Gogoi, N.; Saikia, P. P.; Barua, N. C. Tetrahedron: Asymmetry 2006, 17, 3315-3326. doi:10.1016/j.tetasy.2006.12.005

70. Palomo, C.; Oiarbide, M.; Laso, A. Eur. J. Org. Chem. 2007, 2561-2574. doi:10.1002/ejoc.200700021

71. Fang, B.; Liu, X.; Zhao, J.; Tang, Y.; Lin, L.; Feng, X. J. Org. Chem. 2015, 80, 3332-3338. doi:10.1021/acs.joc.5b00075

72. Tietze, L. F. Chem. Rev. 1996, 96, 115-136. doi:10.1021/cr950027e

73. Tietze, L. F.; Brasche, G.; Gericke, K. M. Domino Reactions in Organic Synthesis; Wiley-VCH: Weinheim, 2006. doi:10.1002/9783527609925

74. Tietze, L. F. Domino Reactions - Concepts for Efficient Organic Synthesis; Wiley-VCH: Weinheim, 2014. doi:10.1002/9783527671304

75. Clavier, H.; Pellissier, H. Adv. Synth. Catal. 2012, 354, 3347-3403. doi:10.1002/adsc.201200254

76. Pellissier, H. Adv. Synth. Catal. 2016, 358, 2194-2259. doi:10.1002/adsc.201600462

77. Pellissier, H. Curr. Org. Chem. 2016, 20, 234-265. doi:10.2174/1385272819666150909235830

78. Feng, B.-X.; Yang, J.-D.; Li, J.; Li, X. Tetrahedron Lett. 2016, 57, 3457-3461. doi:10.1016/j.tetlet.2016.06.084

79. Arai, T.; Tsuchiya, K.; Matsumara, E. Org. Lett. 2015, 17, 2416-2419. doi:10.1021/acs.orglett.5b00928

80. He, Q.; Wu, L.; Kou, X.; Butt, N.; Yang, G.; Zhang, W. Org. Lett. 2016, 18, 288-291. doi:10.1021/acs.orglett.5b03458

\section{License and Terms}

This is an Open Access article under the terms of the Creative Commons Attribution License (http://creativecommons.org/licenses/by/4.0), which permits unrestricted use, distribution, and reproduction in any medium, provided the original work is properly cited.

The license is subject to the Beilstein Journal of Organic Chemistry terms and conditions:

(https://www.beilstein-journals.org/bjoc)

The definitive version of this article is the electronic one which can be found at:

$\underline{\text { doi:10.3762/bjoc. } 14.114}$ 